$\begin{array}{cc}\text { Tür Coğrafya Dergisi } & \text { Turkish Geographical Review } \\ \text { Basılı ISSN 1302-5856 } & \text { www.tcd.org.tr }\end{array}$

\title{
Peynir turizmi temelli kültür rotaları oluşturulmasına yönelik bir araştırma: Van otlu peynir örneği ${ }^{1}$
}

\section{A study on creation of cheese tourism-based culture routes: The case of Van herby cheese ${ }^{2}$}

\author{
Emine Cihangir *a (1) Özlem Demirhan ${ }^{b}$ \\ ${ }^{a}$ Van Yüzüncü Yıl Üniversitesi, Turizm Fakültesi, Turizm Işletmeciliği Bölümü, Van \\ ${ }^{b}$ Van Yüzüncü Yıl Üniversitesi, Sosyal Bilimler Enstitüsü, Turizm İşletmeciliği $A B D$, Van
}

ORCID: E.C. 0000-0001-8514-6655; Ö.D. 0000-0001-7468-2970

\section{BILGI / INFO}

Geliş/Received: 01.12.2020

Kabul/Accepted: 14.12 .2020

\section{Anahtar Kelimeler:}

Peynir turizmi

Kültür rotası

Van otlu peynir

Somut olmayan kültürel miras

Van-Türkiye

Keywords:

Cheese tourism

Cultural route

Intangible assets

Van herby cheese

van-Turkey

*Sorumlu yazar/Corresponding author:

(E.Cihangir) eccihangir@gmail.com

DOI: $10.17211 /$ tcd. 834251

\section{Atf/Citation}

Cihangir, E. ve Demirhan, Ö. (2020). Peynir turizmi temelli kültür rotaları oluşturulmasına yönelik bir araştırma: Van otlu peynir örneği. Türk Coğrafya Dergisi (75), 139-162.

DOI: $10.17211 /$ tcd. 834251

\begin{abstract}
ÖZ / ABSTRACT
Doğu Anadolu Bölgesinde yer alan Van İli, farklı deneyimler yaşamak isteyen turistler için eşsiz doğası, zengin tarihi ve kültürel varlıkları ile alternatif turizm potansiyeline sahip bir kenttir. Bu çalışmanın amacı, Van otlu peynirinin hikayesinin turistik bir ürün olarak pazarlanabilmesi için peynir üretiminin deneyimlenebileceği ve peynir tadımının yapılabileceği peynir çiftliklerinin kurulması ve önerilen peynir çiftliklerine planlanacak tematik kültür rotalarında yer verilebilmesi için turizm sektörü paydaşlarında farkındalık yaratmaktır. Araştırma kapsamında, Van kırsalında üretilen Van otlu peynir üretim sürecinin araştıııması ve üretim süreci arkasında yer alan hikâyenin ortaya konabilmesi için Van'ın dört farklı ilçesinde ön saha çalışması yapılmıştr. Çalışmada peynir yapım sürecini gözlemlemek ve yerel üreticilerin (köylülerin) yaşam koşullarına yönelik bilgi sahibi olmak amacıyla katılımcı olmayan gözlem tekniği kullanıımıştr. Ön saha çalışması sırasında yerel üreticilere sorular yöneltilerek peynir yapım sürecine yönelik ayrıntlı veriler toplanması sağlanmıştı. Araştırmanın ana amacına yönelik boyutunda ise, Van TÜRSAB Bölgesi üyesi olan gönüllü tur acente işletmecileri ve ŞURA üyesi tur rehberleri ile yüz yüze görüşmeler yürütülerek Van otlu peyniri üretim sürecinin deneyimlenmesine yönelik oluşturulabilecek rotaların belirlenmesi sağlanmıştır. Görüşmelerde 5 üye acente ve 3 tur rehberinin görüşleri alınmıştır. Bu görüşler ve araştırmacıların Van ilinde yapmış oldukları saha çalışmaları sonucunda elde etmiş oldukları veriler sentezlenerek Google haritalar aracilığılla potansiyel peynir turizm rotaları oluşturulmuştur. Araştırma sürecinde Van otlu peynirinin turistik bir ürün olarak pazarlanması noktasında henüz kolektif bir bilincin oluşmadığı ve çözülmesi gereken sorunlar olduğu görülmüştür. Bununla birlikte hem yüz yüze görüşmelerde alınan uzman görüşleri hem de saha çalışmalarında yerel üreticilerin bu noktada oldukça istekli oldukları gözlenmiştir. Yakın gelecekte turizm paydaşları ve özellikle yatrımcıların iyi uygulama örneklerinde görüldüğü üzere Van otlu peynirinin hikâyesini turistik ürün olarak pazarlamaları beklenmektedir.
\end{abstract}

Van and its surrounding area have rich historical and cultural assets as well as unique nature. All of which have a wide range of tourism potential for the tourists who wish to experience a wide range of alternative tourism activities. This study aims to raise awareness amongst the tourism sector stakeholders, which might later turn into the establishment of cheese farms in Van's countryside where Van "otlu" (Herby) cheese has a touristic product potential, so that cheese production can be experienced by the domestic and international tourists who wish to experience new alternative tourism activities. To investigate the story behind the cheese production, a preliminary field study was conducted in four different districts of Van. In the study, the researchers also used the non-participant observation technique to observe the cheese-making process and to gather information about the working and living conditions of the individuals involved in cheese making. Besides, during the field study, data were collected about the production process and the details of the cheese-making process by asking the participants various questions. Another main dimension of the research was the focus group interviews conducted with the volunteer tour agencies (chartered by Van TÜRSAB). Employing this method, it is provided to determine the routes which allow those to experience the making process of Van "otlu" Cheese from earlier to the later stages. In the study, five different agencies and three tour guidance's' opinions as well as two NGOs' opinions were benefited. The agencies' opinions and the outcomes of the field studies were synthesized with aim of creating potential cheese tourism routes. At this stage, maps for routes including cheese production experience were drawn through Google maps. As for the marketing of Van "otlu" cheese as a touristic product, it is seen that there is no collective mind yet and there are problems that need to be solved. However, it was observed that both the expert opinions in the focus group discussions and the producers in the field studies were seriously keen on this point. It has been considered that soon, the tourism stakeholders and especially the investors expected to be marketing the Van "otlu" cheese as a touristic product, as it has been seen in the best cases (e.g. Holland, Germany, France).

\footnotetext{
1 Bu çalışmada, Van Yüzüncü Yıl Üniversitesi Sosyal Bilimler Enstitüsü’nde 2.yazar tarafindan hazırlanmakta olan “Turistik Ürün Olma Yolunda Van Otlu Peyniri” isimli yüksek lisans tezinin peynir üretimi ile ilgili saha çalışması verilerinden yararlanılmıştır.

2 This study has been benefited from the data of fieldwork undertaken within the coverage of 2nd author's master thesis on "Van herby cheese on the way of touristic product" which has submitted to the Social Science Institute of Van Yüzüncü Yıl University.
} 
Extended Abstract Introduction

Van and its vicinity area have rich historical and cultural assets as well as unique nature, all of which have a wide range of tourism potential for the tourists who wish to experience alternative forms of tourism activities. This study, therefore, aims to raise awareness among the tourism sector stakeholders to establish cheese farms in Van's countryside where Van "otlu" (Herby) cheese is a touristic product so that cheese production can be experienced by the domestic and international tourists who wish to experience new alternative tourism activities.

In the world, food tourism needs to be integrated and integrated into traditional tourism activities, but in some regions, it becomes the main reason to visit the destination (J. Stanley \& L. Stanley, 2014). Food tourism today is diversified with many specific sub-headings such as wine tourism, beer tourism, chocolate tourism and cheese tourism (Şahin, 2015: 9). Many countries in the world can successfully market food tourism specifically. Cheese tourism has become popular throughout the world, especially in European countries such as France, Switzerland, Italy and the Netherlands. In the literature review about these countries, it has been seen that in addition to local cheese and production techniques, "Cheese Tourism" studies, which have become popular in recent years, take place in various contexts (Fusté Forné, 2015a).

The studies undertaken in the food tourism literature have dealt mainly with the experiences of tourists in the restaurants (Sahin, 2015). Most studies on cheese focused on such topics as cheese types, production processes, content, hygiene, certification (Layton, 1973, Harbutt, 2009; Bogue et al.,1999; Kahraman et al., 2010; Velčovská \& Sadílek, 2015; Uzunsoy \& Özer, 2018); Silva et al.2019; McCarthy et al., 2001). A small number of studies have concentrated on the production process and marketing strategies (Ren, 2011; Uzundumlu \& Topçu, 2016; Fusté Forné, 2015b). In Turkish literature, a large part of research related to food tourism has either focused on local products or the studies of gastronomy tourism of the city (Deveci, 2013; Hatipoglu et al., 2013; Cömert, 2014; Kızılırmak et al., 2014; Aksoy \& Sezgi, 2015; Gökdeniz et al., 2015, Şahin \& Ünver, 2015; Çimen, 2016; Başaran, 2017; Gürsoy, 2017; Özleyen \& Tepeci, 2017; Cömert \& Sökmen, 2017; Çatır \& Ay, 2018; Akdu \& Akdu, 2018; Zengin \& Gürkan, 2019), as well as emphasize the importance of 'geographic sign' in gastronomy tourism (Durlu et al., 2013; Mercan \& Üzülmez, 2014; Polat, 2017). Cheese tourism and cheese trails in Turkey but not specific studies and in particular with some research, the relationship between tourism of local cheeses and made emphasis in terms of the economy of the importance (Atış \& Çelikoğlu, 2017; Arınç, 2018; Kan et al., 2010; Karaca, 2016, Şahin, 2015) and, in a few studies, regional cheeses were mentioned within the flavour routes created for cities (Çakır et al., 2017; Arınç, 2018). In Turkey, Edirne white cheese, cheese, cheddar cheese, 'Kelle' Cheese, 'Mihalic' cheese, Sheep cheese, 'Urfa' cheese as the cheese in the international literature with the general characteristics and taste information emerges (Layton, 1973; Harbutt, 2009: 261; Uzunsoy \& Özer, 2018: 191-192).
With this research, research was carried out to increase the added value of Van herby cheese produced locally in Van and its vicinity in gastronomy and food tourism and to create new cultural routes that include cheese tourism. In this context, the main research questions of the study are presented below; - Does Van herby cheese has the potential to be included in Van Culture routes as a touristic product? - How should Van herby cheese be included in the Van destination culture route as a touristic product? $\bullet$ What is the approach of the tourism sector to the traditional production story of Van herby cheese in the context of alternative tourism?

\section{Data and Method}

The study was carried out at two stages. The data regarding the first phase of the study were planned as preliminary research to provide basic data for the establishment of main research questions and purpose of the study. In the first stage, semi-structured interviews were held in the Cheese market of Van city to figure out the places which might be relevant to follow up the real fieldwork and potential areas to discover regarding cheese production. In addition to this data source, two relevant NGOs' representatives were interviewed. At the second stage of the study, to provide in-depth contextual data for the analysis of local traditions and cultural heritage together with the conditions of the region in both stages of the study conducted in the field, the case study in the qualitative research method was carried out with an interpretive paradigm. First of all, the relevant places were observed with non-participant observation, particularly the cheese-making process of Van 'otlu' cheese. Finally, five tour agents and three tour guidance, as well as the NGOs' representatives, were involved in the second stage of the study to synthesized all gathered information in order them to be turned into the potential experience-based cheese touristic routes which enable the visitors to experience both cheese-making and to visit the cultural and natural assets of the region.

\section{Result and Conclusion}

The interview result of the tour agents, tour guides were also agreed on the potential of cheese tourism which is potentially important not only for the development of rural areas as well as empowerment of the women (cf. Cihangir et al. 2020). Particularly, they suggest that cheese farms provide an opportunity to be the development of cheese-based touristic tours in the region which the cheese-making has been dated back to the ancient times of Urartu Empire. Given that the locals are enthusiastic about the tourism development in the rural areas of the Van basin with the participation of the women, the principal result of this study, two multiple-day routes as well as single-day-based five touristic routes were identified and planned. These routes were mainly built on the cultural and natural heritages of Van basin region. The paper has been finalized with a critical analysis including advantages and disadvantages amongst the routes. 


\section{Giriş}

Gastronomi, sosyal ve fen bilimlerinin ilgili alanları ile özellikle turizm literatüründe hızlı bir şekilde büyüyen en önemli alanlardan bir tanesidir. Gastronomi kültürü, turizm faaliyetleri içinde öne çıkan önemli değerlerden biri olmuştur. Turizm ve gıda arasındaki ilişki, dünya çapındaki turizm destinasyonlarında farklılaşma noktaları olarak kullanılan yiyecekleri deneyimleme firsatlarına göre araştırılmaktadır. Yiyecek turizmi (Food Tourism), yerel yiyecekler ve gastronomi çalışmalarının önemli bir rol oynadığı seyahat faaliyetlerini ifade eder. Yiyecek turizmi olgusunu tanımlamak için gastronomi turizmi, mutfak turizmi, tarım turizmi, yiyecek deneyimleri vb. gibi kullanılan çeşitli terimler vardır (Maurer, 2018: 30). Dünya Gıda Seyahat Birliği (WFTA) raporunda profesyonellerin, akademisyenlerin yiyecek turizmi, mutfak turizmi ve gastronomi turizmi ile ilgili tanımlarının pratikte aynı fenomeni tanımlamak için eşdeğer olduğunu ifade etmektedir (Stone, Migacz, Garibaldi, Stein ve Wolf 2020: 5). Coğrafi bir perspektif ile WFTA, yiyecek turizmini, bir mekânı (yeri) algılamak için mekâna (yere) ait tatları deneyimlemeye yönelik gerçekleştirilen seyahat etme eylemi olarak tanımlamıştır. Bu tanımdan da görüleceği üzere mekan algının yeme-içme deneyimlerine odaklandığı görülmektedir. Yiyeceklerin sadece ekonomik bir metadan daha fazlasını temsil ettiği, turistik çalışmalarla ilgili yer ve kimlik ile maddi ve sembolik ilişkiler arasındaki sorunları birbirine bağlayabilen çok boyutlu bir kültürel yapı olduğu ileri sürülmektedir. Yiyecek turizmi, kültürel açıdan daha bilinçli bir turizm gündemini sürdürmek için kavramsal bir araç sağlamaktadır. Turizm faaliyetlerine katılan birçok turist gittikleri ülkelerdeki yerel lezzetleri deneyimlemekte ve yerel ürünlere yönelik bir bakış açısı geliştirmektedir (Everett, 2008; Ren, 2010). Bu ülkeler ile ilgili yapılan alan yazın taramasında, yerel peynir ve üretim tekniklerinin yanı sıra son yıllarda popüler hale gelen "Peynir Turizmi" çalışmalarının da çeşitli bağlamlarda yer aldığı görülmektedir (Fusté Forné, 2015a).

Dünyanın çoğu bölgesinde yiyecek turizmi geleneksel turizm faaliyetlerine entegre edilmiş ve entegre edilmesi gerekmektedir, ancak bazı bölgelerde destinasyonu ziyaret etmenin ana nedeni haline gelmektedir (J. Stanley \& L. Stanley, 2014). Dünya'da yiyecek turizmini spesifik olarak pazarlamayı başarılı bir şekilde gerçekleştirebilen birçok ülke yer almaktadır. Yiyecek turizmi bugün şarap turizmi, bira turizmi, çikolata turizmi ve peynir turizmi gibi birçok çok spesifik alt başlıklar ile çeşitlendirilmektedir (Sahin, 2015: 82). Örneğin, İtalya, Fransa, İspanya, Avustralya ve Almanya dünyada başarılı şarap turizmine sahip ülkeler arasındadır. Bira turizminde Almanya, Hollanda, Belçika, İngiltere ve Amerika gibi ülkeler "craft" biraları ile bira festivalleri ile ünlüdürler. Peynir turizmi ise özellikle Fransa, ìsviçre, İtalya ve Hollanda gibi Avrupa ülkeleri başta olmak üzere dünya genelinde popüler olmuştur.

Türkiye, tarih boyunca ev sahipliği yaptığı Doğu ve Bat medeniyetlerinin etkilerini taşıyan geniş coğrafyası ve kültürel zenginlikleriyle yiyecek turizmi açısından önemli potansiyele sahiptir. Türkiye'nin özellikle birçok kıtada hâkimiyet kurmuş olan Osmanlı İmparatorluğu mirasına sahip olması, ülkenin mutfak kültüründeki zenginliği yaratan en önemli nedenlerden bir tanesi olarak görülebilir. Bugün UNESCO yaratıcı şehirler listesinde gastronomisi ile yer alan Gaziantep, Hatay, Afyonkarahisar başta olmak üzere Urfa, Adana, Edirne, Muğla, Konya, Kayseri,
Diyarbakır, Çorum, Rize gibi pek çok kent bu anlamda öne çıkmaktadır. Bu haklı ünün ortaya çıkmasında en önemli unsur, geçmişten günümüze farklı kültürlerin yaşam alanları olmuş bu coğrafyalarda kültürel etkileşimlerin, gelenek ve göreneklerin mutfak kültürüne ve sanatlarına aktarılmış olmasıdır. Bu bağlamda, Urartu medeniyetinin başkentliğini yapmış olan Van kenti bölgede yaşamış olan farklı medeniyetlerin izlerini taşıyan kadim bir kenttir. Kentin bölgeye özgü kültürel miraslardan biri olan gastronomisi ise son zamanlarda yerel araştırmacılar tarafindan sürdürülen araşttrmalar ile yeniden yöresel mutfaklardaki yerini almaya ve ziyaretçilere sunulmaya başlanmıştır.

Yiyecek turizmi literatüründe yapılmış olan uluslararası araştırmaların birçoğu özellikle turistin restoranlardaki deneyimlerini temel olarak ele almaktadır (Sahin, 2015). Peynir üzerine yazılan birçok araştırmada ise peynir çeşitleri, üretim süreçleri, içerik, hijyen, sertifikasyon gibi konuların ele alındığı görülmektedir (Layton, 1973; Harbutt, 2009; Bogue, Delahunty, Henry \& Murray, 1999; Kahraman, Ozmen, Ozinan \& Omer Goksoy, 2010; Velčovská \& Sadílek, 2015; Uzunsoy \& Özer, 2018; Silva vd., 2019; McCarthy, O’Reilly \& Cronin, 2001). Çok az bir araştrrmada ise ürünlerin yapım süreci ile pazarlama stratejilerine odaklanıldığı görülmektedir (Ren, 2011; Uzundumlu ve Topçu, 2016; Fusté Forné, 2015b).

Türkiye'de yiyecek turizmi ile ilgili yapılan araştırmaların büyük bir kısmını, yerel ürünler veya kentlerin gastronomi turizmi açısından değerlendirildiği çalışmalar (Deveci, Türkmen \& Avcıkurt, 2013; Hatipoğlu, Zengin, Batman \& Şengül, 2013; Cömert, 2014; Kızılırmak, Albayrak \& Küçükali, 2014; Aksoy \& Sezgi, 2015; Gökdeniz, Erdem, Dinç \& Uğuz, 2015; Şahin Güzel \& Ünver, 2015; Çimen, 2016; Başaran, 2017; Gürsoy, 2017; Özleyen \& Tepeci, 2017; Cömert \& Sökmen, 2017; Çatır \& Ay, 2018; U. Akdu \& S. Akdu, 2018; Zengin \& Gürkan, 2019) ile coğrafi işaretlemenin önemine vurgu yapan çalışmalar oluşturmaktadır (Durlu Özkaya, Sünnetçioğlu \& Can, 2013; Mercan \& Üzülmez, 2014; Polat, 2017).

Türkiye'de peynir turizmi ve peynir rotaları özelinde ise yapılmış özel bir çalışma olmamakla beraber bazı araştırmalarda yöresel peynirlerin turizm ile ilişkisine ve önemine bölge ekonomisi açısından vurgu yapmışlardır (Atış \& Çelikoğlu, 2017; Arınç, 2018; Kan, Gülçubuk, Kan \& Küçükçongar, 2010; Karaca, 2016; Sahin, 2015) ve birkaç çalışmada ise kentler için oluşturulan lezzet rotaları içinde yöresel peynirlere değinilmiştir (Çakır, Çiftçi \& Çakır, 2017; Arınç, 2018). Türkiye peynirlerinden Edirne beyaz peyniri, Kaşar peyniri, Kelle peyniri, Mihaliç peyniri, Tulum peyniri, Urfa peyniri ise tat ve genel özellikleriyle az sayıda uluslararası literatürde yer alan peynirler olarak karşımıza çıkmaktadır (Layton, 1973; Harbutt, 2009: 261; Uzunsoy \& Özer, 2018:191-192).

Van otlu peyniri ile ilgili yapılan araştırmaların ise büyük bir kısmı gıda veya ziraat mühendisleri tarafindan yapılan peynirin üretim süreçleri ile ilgili olarak kimyasal ve fiziksel özelliklerine ya da kullanılan otların özelliklerine ve çeşitliliklerine değinilen çalışmalar ile sınırlı kalmıştır (Coşkun \& Öztürk, 2001; İşleyici \& Sancak, 2005; Akyüz, Coşkun, Andiç, \& Altun 1996; İşleyici \& Akyüz, 2009; Tarakçı \& Küçüköner, 2006; Tunçtürk, Ocak \& Köse, 2014; Ocak \& Köse, 2015; Kurt \& Akyüz, 1984), bir kısım çalışmada ise Van'da yaşayan ailelerin otlu peynir alım ve tüketim alışkanlıkları (Şahin, Andiç \& Koç, 2001) ile peynirin coğrafi 
işaretleme almasının tanıtımına katkısı ve geleneksel yapım tekniklerinin korunmasının sürdürebilirlik açısından önemi (Yenipınar, Köşker \& Karacaoğlu, 2014) ele alınmıştır. Van otlu peyniri, uluslararası literatürde ise bazı araştırmalarda sadece isim olarak yer almaktadır. (Uzunsoy \& Özer, 2018: 191, Öney Tan, 2016: 734, Oliaei, 2016: 390).

Bu araştırma ile Van ve yakın çevresinde yerel olarak üretilen Van otlu peynirinin gastronomi ve yiyecek turizminde yaratacağı katma değerin artırılması ve peynir turizmini de içine alan yeni kültür rotalarının oluşturulmasına yönelik araştırma yürütülmüştür. Bu bağlamda çalışmanın ana araştırma soruları aşağıda sunulmuştur;

- Van otlu peynirinin geleneksel üretimi hikâyesinin alternatif turizm bağlamında deneyimlenmesine turizm sektörünün yaklaşımı nasıldır?

- Van otlu peyniri turistik bir ürün olarak Van Kültür rotalarında yer alabilir mi?

- Van otlu peyniri turistik bir ürün olarak Van destinasyonu kültür rotasında nasıl yer almalıdır?

Yukarıda ifade edilen araştırma sorularına yanıt vermek amacıyla çalışma kapsamında hem saha çalışması hem de detaylı bir literatür incelemesi gerçekleştirilmiştir. Bu araştırmanın yiyecek turizmi bağlamında özel bir tema olarak tanımlanan peynir turizmi noktasında Türkiye'de uygulanabilmesi ve geliştirilmesine yönelik önemli bir kavramsal ve uygulama altyapısı sağlayacağı düşünülmektedir.

\section{Literatür Taraması}

2.1. Peynir Turizminin Türkiye'deki ve Dünyadaki Durumunun İncelenmesi

Van otlu peynirinin turistik ürün olarak kente katacağı katma değerin büyüklüğü peyniri turistik ürün haline getirmiş ulusal ve uluslararası düzeyde iyi uygulamalar incelendiğinde görülebilmektedir. Bu anlamda, Doğu Anadolu Bölgesi'nde Kars iline bağlı Boğatepe (Zavot) köyü önemli bir ulusal örnek olarak karşımıza çıkmaktadır. Kars gravyeri Kars için önemli bir turistik ürün haline gelmiştir. Boğatepe'de hem üretim mandıraları hem de 2011 yılında kurulan Zavot Eko Müzesi her yıl binlerce turist tarafindan ziyaret edilmektedir. Müzede Boğatepe ve Kars'ın gravyer ve peynir tarihini sunulmakta, eski eski peynir kalıpları, maya kaıpları, tart ağırlıkları gibi peynir yapımıyla ilgili malzemeler yer almaktadır (Türkiye'nin ilk peynir müzesi, 2019) (Fotoğraf 1).
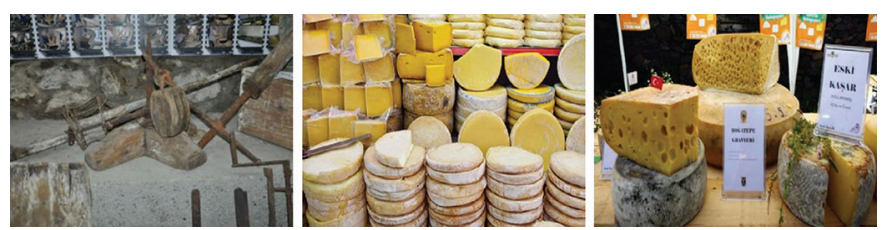

Fotoğraf 1. Zavot Peynir Müzesi, Boğatepe-Kars

Photo 1. A view from Zavot Cheese Museum in Boğatepe village of Kars

Yine son yıllarda dünyada lezzet açısından ilk beş peynir arasında yer bulduğu iddia edilen Divle obruk peyniri (Konya-Karaman) \%90 nem oranına sahip olan obruk mağaralarında olgunlaştırılan peynirler mağaraların mikro florasından dolayı kendine özgü küflenmekte ve özel bir tat oluşmaktadır. Türkiye'nin her yerinden ziyaretçiler ve yurtdışından ziyaretçiler peynir için Divle'ye gelmektedirler (Divle Obruğu, 2019) (Fotoğraf 2).
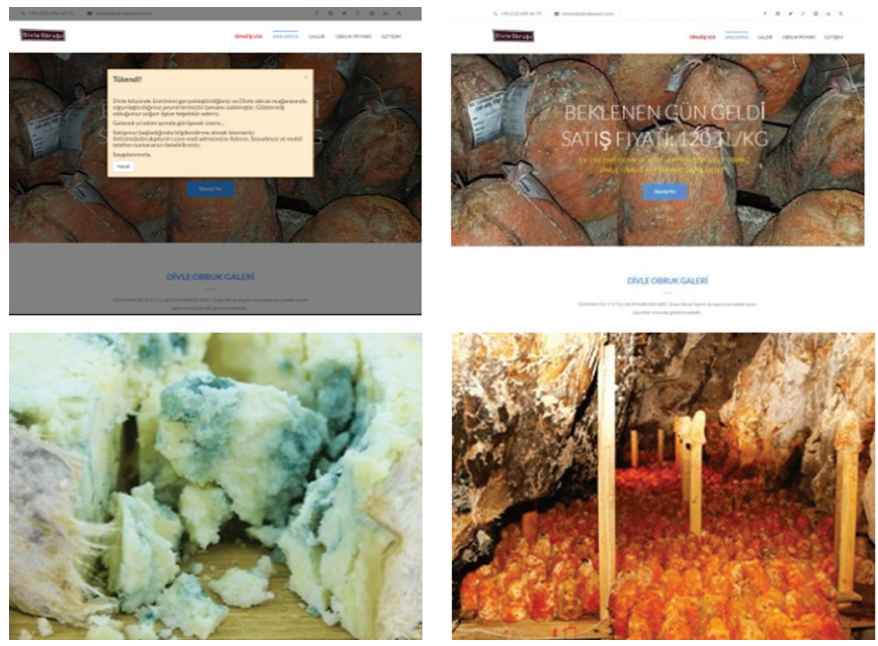

Fotoğraf 2. Divle obruğu görselleri, Konya-Karaman

Photo 2. A view of 'Divle Obruğu' cheese in Karaman, Konya

Uluslararası boyutta ise Fransız gastronomisinin en önemli simgesi ve Fransa'nın köken adlandırmalı en eski peyniri olan Rokfor, bin yılı aşkın süredir devam eden ününü yerel geleneğe dayalı peynir kültürüne ve Roquefort köyünde yer alan ve olgunlaşma sürecinin gerçekleştiği kalker mağaralarına borçludur. Rokfor peyniri, Fransa'nın ihracat gelirlerinde önemli bir yer tutmanın yanı sıra her yıl mağaralara gelen yerli ve yabancı ziyaretçilerin bıraktıkları turizm gelirleri ile yöre ekonomisine önemli katkılar sağlamaktadır (Tekelioğlu, 2011: 70,74-75, Cunningham, Shukla \& Tikkanen, 2007).

Hollanda'daki peynir endüstrisi başlıca ekonomik etkenlerinden biridir. Ülke ekonomisinde peynir ihracat yıllık 7 milyar avro değer yaratmaktadır (Dutch Cheese Shops, 2019). Hollanda pek çok peynir çeşidine sahiptir. En yaygın bilinen Gouda ve Edam'dır. Hollanda'da peynirin turizmi önemli katma değer yaratmaktadır. Ülkede önemli bir gelenek olan ve 1365 yılından itibaren 27 Mart - 25 Eylül tarihleri arasında her Cuma günü kurulan "Alkmaar Cheese Market" 30.000 kiloya kadar veya 2200 adet dizilmiş yuvarlak peynir ile Alkmaar kentine ziyaretçilerini beklemektedir (Alkmaar Cheese Market, 2019) Hollanda Peynir Müzesi, Alkmaar'daki Cheese Weigh House'da yer almaktadır (Alkmaar Cheese Museum, 2019) (Fotoğraf 3).
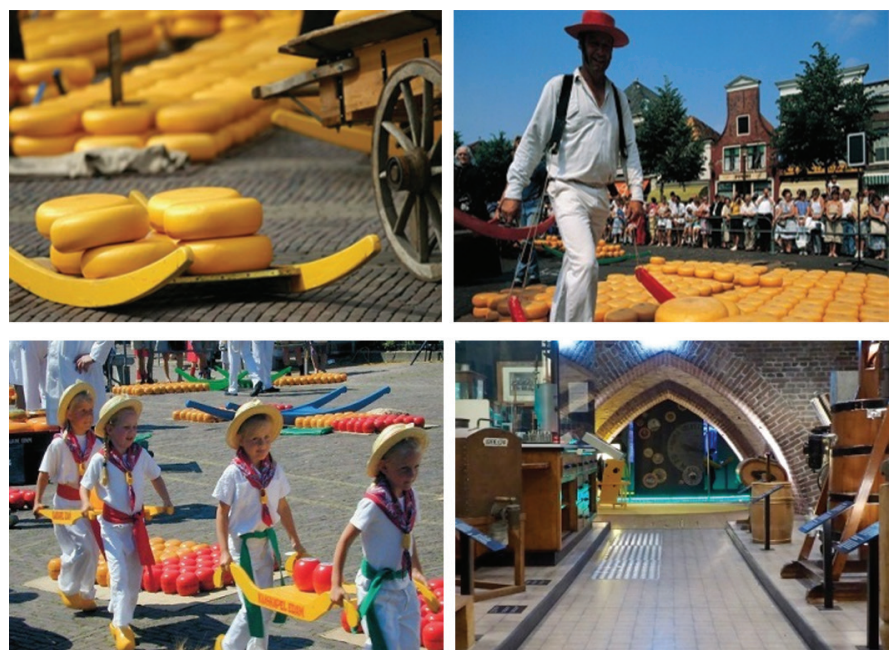

Fotoğraf 3. Hollanda Alkmaar Peynir Pazarı ve Alkmaar Peynir Müzesi görüntüleri

Photo 3. A view of Alkmaar Cheese Market and Cheese Museum from Alkmaar province of Holland 
Yine 1395'te başlatılan Gouda Peynir Pazarı'nda Gouda peyniri satışı yapılmaktadır. Gouda Peynir Pazarı, perşembe sabahları nisan-ağustos ayları arasında yapılmaktadır (Gouda Cheese Market, 2019). Edam peynir pazarı 1520 yılından itibaren ku-rulmaktadır. Edam, çiftçi peynir pazarı yaz aylarında her çar-şamba günü kurulmaktadır (Fotoğraf 4).
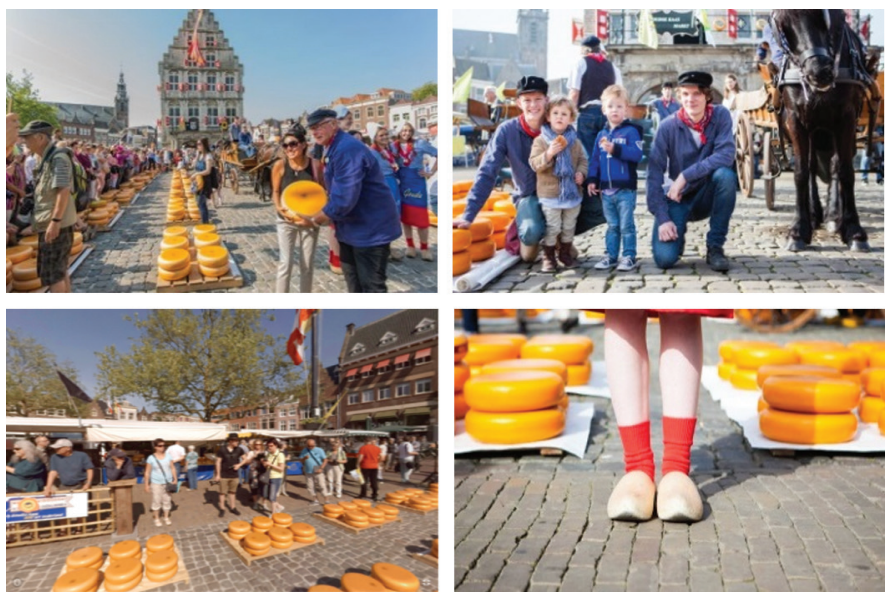

Fotoğraf 4. Gouda Peynir Pazarından (Gouda, Hollanda) görüntüler Photo 4. A view of Gouda Cheese Market (Gouda, Hollanda)

Amsterdam yakınlarında yer alan "The Henri Willig Group"un sahip olduğu Alida Hoeve (Zeddeweg 1, Volendam), Jacobs Hoeve (Hoogedijk 8, Katwoude) ve Catharina Hoeve (Zeilen-makerspad 5, Zaandam) çiftlikleri en önemlileri arasındadır. Henri Willig'in çiftlikleri bugün önemli bir turistik cazibe merkezi haline gelmiştir. Şirket dükkanlarında ve peynir çiftliklerinde milyonlarca ziyaretçiyi ağırlamakta ve özel peynirlerini 35'ten fazla ülkeye ihraç etmektedir (Visit Our Cheese Farms, 2019) (Fotoğraf 5).
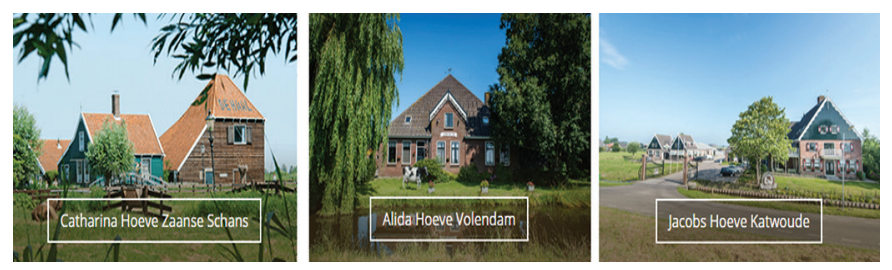

Fotoğraf 5. Hollanda'nın çeşitli bölgelerinde bulunan peynir çiftliklerinden görüntüler

Photo 5. A view of cheese farms from different regions of Holland

Benzer şekilde Avrupa'da peynir yapımı ile ilgili turlar incelendiğinde karşımıza pek çok ülke ve kent çıkmaktadır. Örneğin; ziyaretçiler için farklı seyahat deneyimleri sunma iddiasında olan Tripaneer Şirketi tarafından sunulan "Top 10 listings for Cheese making tours" listesini incelediğimizde Avrupa'da yer alan peynir üretim merkezilerine yönelik turlar detaylı bir şekilde görülebilmektedir (Eurobound Launches New Europe Tours For Cheese Lovers, 2019). Örneğin kişiye özel Avrupa seyahat paketleri sunan "Eurobond" şirketi, peynir sever-lere yönelik özel deneyimler içeren turlar sunmaktadır. Özel peynir deneyimleri içeren tur paketleri ayrı olarak sunulduğu gibi turlar şarap ve peynir günü, bağ ziyareti, pazar yürüyüşü veya usta bir aşçı ile yemek dersi gibi daha geniş kapsamlı bir program içinde de programlanabilmektedir. Eurobound peynir temalı paketler arasında çiftlik evlerinde konaklamalar, birinci sınıf restoranlarda rezervasyonlar ve tüm seyahat düzenlemeleri yer almaktadır. Şirketin sunduğu peynir odaklı turistik deneyimlerden biri Fransa Loire Vadisi ziyaretidir. Konuklar, el yapımı keçi peyniri üreten bir aile işletmesi olan La Cabinette keçi peyniri çiftliğini ziyaret edip peynirin nasıl yapıldığını öğrenmekte, keçileri görebilmekte ve peynir tadımları yapabilmektedirler. Bir diğeri, ParisPeynir mahzenine kişiye özel ziyarettir. Özel bir rehber aracılı̆̆ıyla peynir yapım sürecinin detayları açıklanmakta, ardından şarap ve şampanya ile tamamlanan bir tatma süreci ile tur tamamlanmaktadır. Yine Fransa'daki Burgundy-Gaugry Family çok özel peynir ziyaret noktalarından bir tanesidir. Ziyaretçiler, nesilden nesile aktarılan bilgi ile devam eden bir peynir üreticisi olan Gaugry ailesinin peynir süt ürünleri üretim merkezini ziyaret ederek çiğ sütten Epoisses peynirinin üretim süreci deneyimlemektedir. Epoisses, Ami du Chambertin ve Plaisir au Chablis gibi yıkanmış kabuklu inek sütü peynirlerinin nasıl yapıldığını öğrenmektedirler.

İtalya'da düzenlenen turlardan biri ise Azienda Agricola Guareschi'deki İtalya Yemek Vadisi-Parma tatma turudur. Parmigiano Reggiano peynirini keşfetmek için Guareschi Çiftliği ziyaret edilmektedir. Diğer tur ise Pienza-Fattoria Pianporcino-Pecorino di Pienza tadımı turudur. Güney Toskana'daki koyun çiftliğinde, müşteriler sütün bölgenin eşsiz Pecorino di Pienza'sına nasıl dönüştürüldüğünü öğrenmektedirler. Burada, yerel geleneği takip ederek, fındık, yaprak, saman ve otlar ile tatlandırılmış peynirler de dahil olmak üzere, başka yerlerde bulunmayan 30'dan fazla Pecorino türünün tadımını gerçekleştirmektedirler. Şirket aynı zamanda daha Hollanda'nın Amsterdam kentindeki ünlü peynir ustalarının dükkanlarına, Edam-Peynir Pazarının, Gouda-Peynir Pazarına turlar düzenlemektedir. Müşteriler, renkli Edam Peynir Pazarı'na yapılan bu 3 saatlik turda peynir satıcılarını çalışırken gözlemlemektedir.

Benzer şekilde Cheese Journeys (https://www.cheesejourneys.com/\#intro-section) "Yemek, şarap ve el yapımı peynir severler için seçilmiş gezi turları!" sloganı ile pazarlama yaparak Amerika'dan Avrupa'ya uzanan çiftlik ziyaretleri içeren çeşitli tur programları ile peynir severleri bir araya getirmekte, The Cheese Tour (https://thecheesetour.com/) Amerika'da Exclusive France Tours (https:// www.exclusive-france-tours.com/en/) Avrupa'da benzer turlar düzenlemektedir.

\subsection{Turizm Rotaları ve Tematik - Kültür Rotaları}

Ziyaretçilerin tarihi, doğal ve kültürel değerleri barındıran turizm faaliyetlerine artan ilgisi hem yerel yönetimlerin ve hem de turizm faaliyetlerinde paydaş olarak yer alan tüm bileşenlerin ortak değerlere sahip çıkmasını, sürdürülebilir bir turizm anlayışı çerçevesinde bu değerlerden faydalanarak kent ve yerel halk için ekonomik bir değer yaratmasını sağlayacaktır. Turizm rota çalışmaları özellikle kırsal kesim ve ekonomik gelişmişlik düzeyi düşük bölgeler için bütünsel bir yaklaşım ile ele alındığında yeni ekonomik değer üretecek faaliyet alanları sunabilmektedir. $\mathrm{Bu}$ anlamda rota çalışmalarında özellikle yerel yönetimlerin ve yerel halkın işbirliği önemlidir (ÇEKÜL, 2014: 32). 
Çağdaş post-modern ziyaretçiler, kırsal alanların kaynaklarını kullanarak sağlayabilecekleri otantik ve benzersiz deneyimler ararlar (Jarábková \& Hamada, 2012: 8). Bu yaklaşım içinde ziyaretçiler seyahatleri sırasında yöreye özgü kültürel değerleri deneyimleyebilecekleri atölye çalışmalarının yer aldığı, yerel çiftliklerde çeşitli tarımsal/hayvansal üretim faaliyetlerine katılabilecekleri veya yerel yiyecek/içecekleri birlikte yapma ya da yapım süreçlerini deneyimlemeye yönelik faaliyetler içeren destinasyonları ve rotaları tercih etme eğilimi içerisindedirler. Bu anlamda, turizm rotaları (tematik/kültür) çeşitli aktiviteleri ve cazibe merkezlerini birleşik bir tema altında bir araya getirerek ziyaretçilere bunları tek bir tema altında sunmayı ve böylece yan ürün ve yeni hizmetlerin geliştirilmesi yoluyla yerel girişimcilik fırsatlarını teşvik etmektedirler. Bu nedenle rotalar, turizm destinasyonun gelişimine pazar odaklı bir yaklaşımdır (Meyer, 2004: 3; Meyer, Ashley \& Poultney, 2004; Lourens, 2007: 475; Stoddart, 2008: 32). Tematik rotalar doğal, kültürel ve tarihi potansiyelin çeşitli kısımlarını birbirine bağladığı gibi şarap rotaları, peynir rotaları süt ve bira rotaları gibi yerel gastronomi etkinlikleri ya da yöresel el sanatları gibi faaliyetleri deneyimlemek üzere belirlenebilmektedir (Kervankıran \& Çuhadar, 2014: 578; Jarábková \& Hamada, 2012: 8).

Uluslararası deneyimler, iyi tasarlanmış ve yaratıc turizm rotalarının destinasyonlar için çeşitli olumlu avantajlar sağlayabileceğini doğrular niteliktedir (Rogerson, 2009:31). Rotaların sağladığı en önemli avantajlardan biri ünlü destinasyonların ötesine seyahat etmek istemeyen ziyaretçileri, zaman ve para harcamaya ikna etme potansiyeline tek başına sahip olmayan gölgede kalmış yerler ile ilgi çekici yerleri bağlayarak yaratılan ikna etme gücü olabilir (Schmudde \& Sörensson, 2020: 59). Aynı zamanda bir rota, ziyaretçilerine "yeni" özellikler sunarak bir ürünün genel çekiciliğini artırabilir, böylece kalış süresini ve toplam harcamayı artırmak amacıyla revize edilmiş pazarlama programları için bir platform sağlar (Meyer vd., 2004; Meyer, 2004: 3). Rotalar ayrıca ziyaretçilerin parasını daha fazla sayıda alıcı arasında dağıtır.

Kültürel miras ve turizm kavramları birbirlerini besleyen çok boyutlu yapılardır. Kültürel mirasın korunması ve devamlıIığının sağlanması kültürel turizmin varlık sebebidir (Yetkin, \& Çamur, 2019: 40). Kültür rotası kavramı kültürel mirasın korunması teorisi ve pratiğine niteliksel olarak yeni bir yaklaşım getirmekte ve temsil etmektedir. Kültürel rotalar, her bir öğenin gerçek değerine saygı göstererek, tüm öğelerinin değerini bir bütünün temel parçaları olarak tanır ve vurgular. Ayrıca, sürdürülebilir sosyal ve ekonomik kalkınma için bir kaynak olarak kültürel miras değerlerinin çağdaş sosyal anlayışını göstermeye yardımcı olmaktadır. Bu bağlamda seyahat etme niyeti olan kişiler için tarihi ve kültürel değerleri içerecek şekilde hazırlanacak kültürel rotalar önemli bir seçenek sunmaktadır. Kültür rotaları temel olarak bir bölgenin doğal çevre bileşenleri ile o bölgeye ait somut ve soyut kültürel mirasını kapsar. Rotalar tarihte kulla- nılmış bir güzergahın yeniden canlandırılması şeklinde olabileceği gibi (İpek Yolu, Baharat Yolu gibi) günümüzde belirli öğeler birleştirilerek özel amaçlar için de (ünlü ressamlar, müzisyenler, yeme-içme gibi) yaratılabilmektedir. Bir kültür rotası oluşturmak için; birbiriyle ilişkili olacak şekilde doğal oluşumlardan göller, dağlar, yaylalar, mağaralar; yaban hayata ait endemik hayvanlar veya bitkiler, somut kültüre miras içinde camiler, kiliseler, kaleler gibi tarihi yapılar, antik eserler veya yerleşim yerlerine ilişkin kalıntılar, somut olmayan miras olarak da el sanatları, söylenceler, yeme-içme kültürü, gelenekler gibi bileşenlerden bir ya da birkaçı bir araya getirilebilir. Bu bileşenlerin belirli bir tema oluşturacak şekilde bir harita üzerinde coğrafi yerlerinin tanımlanarak bir süreklilik oluşturacak biçimde nokta ya da çizgi ile işaretlenmesi gerekmektedir (Görmüş, 2017; ÇEKÜL, 2014: 13).

\subsection{Peynir Turizminin Yeni Turizm Paradigmaları İçerisinde} Yeri

Ziyaretçiler günümüzde alternatif turizm türlerine -deneyim turizmi, özel ilgi turizmi, eko turizm, dönüşüm turizmi vb. gibi yoğun ilgi göstermektedirler. Kitle turizm hareketine dahil olmak istemeyen, doğal değerlere ve çevreye duyarlı, gittikleri bölgenin somut ve somut olmayan kültürel mirasını ve tarihi dokusunu hissetmek isteyen bu ziyaretçiler yerel halk ile iletişim kurmaktan, yerel kültürel değerleri ve yaşamı deneyimlemek ve özümsemek isteyen bir anlayış ile tatil seçeneklerini belirlemektedirler.

Kesici (2012) yaptığı çalışmada, turizm algısının değiştiğini, insanların deniz, kum, güneş üçlemesinin dışına çıkarak ziyaret edecekleri yerlerde kültürel ve sosyal değerlere önem verdiklerini bu anlamda turistik ürünlerin öneminin arttığını vurgulamaktadır. Ayrıca turistik ürünü tamamlayıcı etkenlerinin olduğunu bu etkenlerin güvenlik, sağlık, ulaşım vb. olduğunu belirtmektedir. Akgöz, Göral \& Tengilimoğlu (2016) turizm rekabetinin devamı için destinasyonların sürdürebilir olmasına ve bunun da ürün çeşitlendirilmesi ile olabileceğine işaret ederek turistik ürünlerin turizm sürdürebilirliği açısından önemini belirtmektedir. Özkan \& Aydın (2018) turizmin, sürdürülebilirlik çerçevesinde bölgelerin sahip olduğu kültürel değerlerine sahip çıkması gerektiğini ve somut olmayan kültürel değerler arasında yer alan yerel yemek kültürünün korunarak gelecek nesillere aktırılmasının destinasyonların sürdürebilirliği açısından önemine vurgu yapmaktadır.

Alternatif turizm, yiyecek turizmi, deneyim turizmi bağlamında peynir turizmi ele alındığında günümüzde bu turizm türlerini talep eden post-modernizmle birlikte ortaya çıkan yeni turist tiplerinin vurgulanması gerekmektedir. Urry (2009)'nin çalışmasında post-turist olarak ifade ettiği bu turistlerin temel özelliklerinden biri kendi sosyal ve kültürel öğelerinden sıyrılmalar yaşayarak daha bireysel hareket edebilmeleri ve mekânın yapaylığının farkında olmalarıdır. Diğer önemli bir özellikleri ise deneyimlemeye yani deneyimsel ve yerele katkı 
sunabilecek yeniden üretim süreçlerine destek olabilecek turistler olduklarıdır. Bu çerçevede turizmin bileşeninin sürdürülebilir kalkınmadaki en önemli rollerinden biri çevrenin korunması olmakla birlikte aynı zamanda yereldeki eşitsizliklerin giderilmesi, yerelin kalkınması ve cinsiyet eşitsizliği konularında çözümler üretmesinin beklenmesidir. Bu bağlamda, peynir turizmi üretim çiftlikleri yerelde kadının üretim süreçlerine dahil olmasını, kadının güçlenmesini sağlayacağı gibi post-modern turistlerin deneyimleme ve otantiklik beklentilerini de karşılayacak potansiyele sahip olması anlamında önemlidir.

\subsection{Van Otlu Peynirine Tarihi Perspektiften Bakış}

Van kenti turistlerin yoğun ilgisini çekebilecek eşsiz coğrafyası, pek çok medeniyete ev sahipliği yapmış zengin tarihsel dokusu ve kültürel varlıklarının yanı sıra zengin bir yerel yiyecek kültürüne sahiptir. Bu anlamda önemli yerel yiyeceklerinden biri de Van otlu peyniridir. Son yıllarda Van kahvaltısı geleneğinin bilinirliğinin artmasıyla kahvaltının en önemli bileşenlerinden biri olan Van otlu peynirine olan ilgi de artmıştır. Ancak, tarihsel süreç incelendiğinde Van otlu peynirinin, Van kahvaltısının ünlü olmasından çok daha önce yörenin önemli bir yerel yiyeceği olarak bilindiği ve talep gördüğü anlaşılmaktadır.

Bu peynirin ilk olarak ne zaman ve nasıl yapıldığı tam olarak bilinmemekle beraber, Osmanlı topraklarını 1630'lu yıllardan başlayarak 1681'e kadar kırk yıldan uzun süre gezen ve gördüklerini Seyahatname adlı eserinde toplamış olan Evliya Çelebi Van ve yöresini birden fazla kez ziyaret etmiştir. Çelebi, eserinde yöreye özgü yiyeceklerden bahsederken, otun katık yapıldığı bir peynirden de bahsetmektedir (Okumuş, 2008: 188). Van ilinin bitki örtüsünün zenginliği ve sert iklim şartları ile ulaşım imkânlarının yetersizliği; geçmişte halkın geçim kaynağının hayvancılığa dayalı olması ve halkın konup-göçerlik hayatı yaşaması, yabani otları yakından tanımasını sağlamış ve otlu peynir geleneğini oluşturmuştur (Türk Patent ve Marka Kurumu, 2018). Van otlu peynirine dair halk arasında anlatılan rivayete göre, şiddetli ve uzun süren kış mevsimi nedeniyle çevreyle ilişkisi kesilen bölgede -yeterince iyi beslenememe ve vitamin eksikliği nedeniyle çok hastalık yaşanmaktaydı. İran'dan gelen Ermeni asıllı bir doktorun bazı hastalıkların tedavisi için ilaç olarak çeşitli otlar katarak hazırladığı peyniri kullandığı, önceleri ilaç olarak kullanılan bu otlu peynirin zaman içinde halk tarafından benimsenerek sofralarının vazgeçilmez ana besin kaynağı olduğu anlatılmaktadır (Yenipınar, Köşker \& Karacaoğlu, 2014: 16).

Van otlu peynirinin tarihine ilişkin yeni bulgular ise son yıllarda yapılan araştırmalar ile ortaya konmuştur. Van'ın Gürpınar ilçesinde bulunan Hoşap Kalesi'nde Öğretim Üyesi Dr. Mehmet Top başkanlığında yapılan 2015 yılında yapılan kazı ve restorasyon çalışmaları sırasında 4 adet insutu ${ }^{3}$ vaziyette

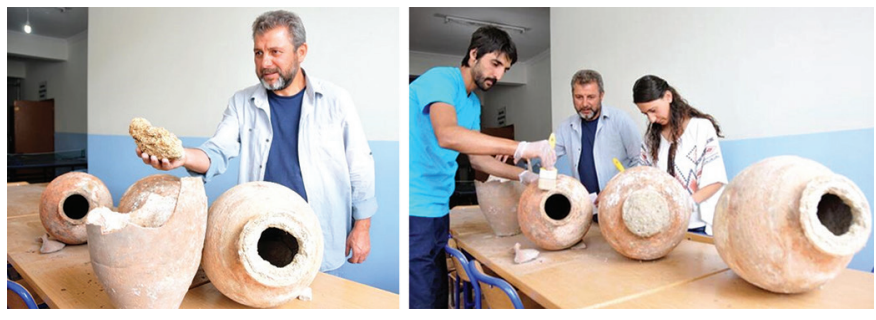

Fotoğraf 6. Hoşap Kalesi'nde bulunan küpler ve tortu haldeki peynir kalıntısı Photo 6. A view of cheese residual within the ceramic pots which was found in Hoşap Castle

pişmiş toprak peynir küpü bulunmuştur (Fotoğraf 6).Küplerin ağızlarının toprak mühürlü olduğu ve içinde bulunan tortulaşmış kalıntıların otlu peynir olduğu yapılan analizler sonucunda anlaşılmıştır (Top, 2017: 596). Ortaya çıkarılan küpler içerisinde bulunan peynirin 200-250 yıllık olduğu düşünülmektedir (Van'da 250 Yıllık Otlu Peynir Bulundu: 2015).

\subsection{Van Otlu Peynirinin Üretimi}

Van otlu peynirinin turistik bir ürün haline getirilmesi düşünülen üretim hikâyesinin teknik üretim süreci şu şekildedir; peynir üretimi ilkbahar aylarında başlayıp süt verimine ve hava şartlarına bağlı olarak Ağustos ayının sonuna kadar sürebilmektedir. Peynir üretimine başlamadan önce peynire katılacak olan sirmo/sirik, mendi/mendo, heliz, yabani nane, kekik, siyabo gibi otların hazırlanması gerekmektedir. Baharın gelmesiyle beraber yaylardan, dağlardan toplanan otlar, yıkanıp doğranarak ve kazanlarda peynir altı suyu içinde sarartılıp kullanıma hazır hale getirilmektedir. Otlar peynir altı suyu ve tuz karışımından oluşan salamura suyu içerisinde korunur ve yaklaşık olarak 6 ay boyunca otlu peynirin üretimi süresince kullanılmaktadır. Nisan sonu mayıs ayı başında hayvanların yaylaya çıkartılmaya başlamasıyla süt verimi de artmaya başlamaktadır. Haziran-temmuz-ağustos aylarında ise peynir üretimine başlanmaktadır. Peynir üretiminde ağırlıklı olarak koyun sütü kullanılmaktadır. Bazı yörelerde koyun ve keçi karıştırılarak ya da sadece inek sütü ile üretim de yapılabilmektedir. An-cak, inek sütü Van yöresinde çok fazla tercih edilmemektedir (Fotoğraf 7).
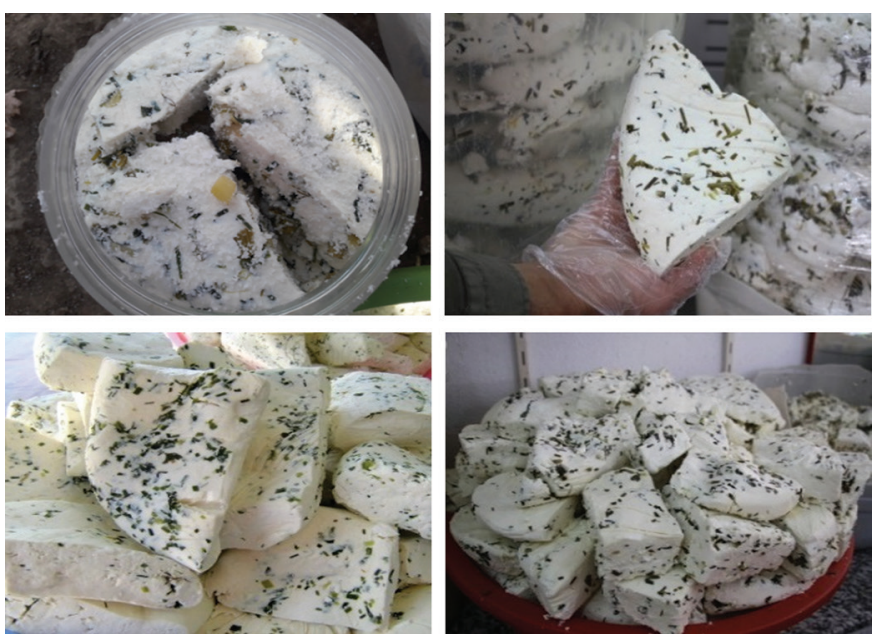

Fotoğraf 7. Van otlu peyniri görselleri Photo 7. A view of Van herby cheese

\footnotetext{
3 In situ: Arkeolojik bulunan kalınt ya da eserin işlevinin gerektirdiği yerde bulunduğunu anlatır (In situ: 2019).
} 
Peynir eskitme yöntemi ile olgunlaştırılarak veya salamura yöntemi ile hazırlanarak tüketime sunulabilmektedir. Her iki yöntemde de peynirin mayalanması ve yöresel otlar ile karıştırılması aynı süreci içermektedir. Süt sağıldıktan sonra süzülerek henüz ılık haldeyken çiğ olarak mayalanmaktadır. $\left(30 \pm 2^{\circ} \mathrm{C}\right.$ kadardır (Ocak \& Köse, 2015: 344). Mayalama için geleneksel olarak şırdan ve farklı otlar ile hazırlanan maya kullanılmaktadır. Süt ortam sıcaklığına ve maya miktarına göre yaklaşık 2-3 saat içinde mayalanarak pıhtı kıvamına gelmektedir. Bu pıhtı parçalanarak bez bir torba içine bir kat ot bir kat mayalanmış pıhtı olarak ya da yabani otların tümü pıhtıya karıştırılarak konulmaktadır. Daha sonra bez torba süzülmesi için uygun bir yere konularak (tahta vb. gibi) 4-6 saat arasında serin bir ortamda bekletilmektedir. Süzülme işlemi bittikten sonra yuvarlak bir şekli olan peynir genellikle $12 * 15 \mathrm{~cm}$ ölçülerinde göz kararı kesilerek kaya tuzu ile tuzlanarak günümüzde plastik bidonlar içine konulmaktadır. Başlangıçta su ile doygun ve yumuşak olan peynir bu şekilde öz suyunu bırakarak sertleşmeye başlamaktadır. Salamura olarak bilinen bu yöntem ile hazırlanan peynirin tüketime sunulması için en az 20 gün boyunca peynirin kendi bıraktığı tuzlu su içerisinde kalması gerekmektedir. Bu süre sununda eskitme yöntemi yapmak için salamuradan çıkarılan peynir parçaları temiz su ile yıkanarak cacık - peynir altı suyu kaynatılarak kaynama esnasında üzerinde oluşan beyaz çökelekten yapılan ve tercihe göre sade ya da peynire katılan otlardan katılarak kullanılan- ile genellikle plastik bidonlara veya geleneksel olarak üretilmek isteniyorsa toprak küplere bir kat peynir bir kat cacık şeklinde hiç boşluk kalmayacak şekilde yerleştirilir. Cacık, hem peynir parçaları arasında boşluk oluşmamasını sağladığı hem de peynire kendine has bir tat sağladığı için kullanılmaktadır. Dolum işlemi bitince bidonların ağzı biraz lor ya da cacıkla kapatılıp üzerine "Suh" ya da "Evelik" otu konulur ve son olarak kil ile sıvanır veya bir bez ile örtülür. Sonrasında serin bir yerde olgunlaşt-rılmaya bırakılmak üzere bidonlar ters çevrilerek toprağa gömülmektedir. Eskitme yöntemi ile olgunlaştırma süreci 3-5 ay sürebilmektedir. Eskitme yapılmayan salamura peynirler istenirse 20 günlük süre sonra tüketime sunulabilir ya da yine toprak altında ancak bu kez bidonlar ters çevrilmeden saklanarak daha sonra tüketime sunulabilir.

\subsection{Van Otlu Peynirinin Hikayesinin Turistik Ürün Niteliği}

Turistik ürün, "çağdaş insanın çok boyutlu gereksinimlerini karşılamak üzere turizm işletmesince bir araya getirilmiş ve yeniden düzenlenmiş doğal, toplumsal, siyasal ve psikolojik verilerden oluşan karmaşık bir mal ve hizmet bütünüdür" (Usal \& Oral, 2001'den akt. Çolakoğlu, 2014: 51). Hacıoğlu (2000: 39) turizmde ürünün iki biçimde ortaya çıktığını ifade etmektedir; ilki, bir yörenin ya da ülkenin sahip olduğu tarihi ve doğal varlıkların yarattığı turizm ürünüdür. İkincisi ise, tatil yapmak isteyen tüketiciler için paket tur içinde sunulan tu-ristik hizmetler bütünüdür. Turistik ürünü oluşturan unsurlar arasında çekicilik, ulaşılabilirlik ve turizm işletmeleri sayılabilir (Hacıoğlu \& Avcıkurt, 2011: 5). Kesin bir turistik ürün tanımı olmamasına rağmen (Hacıoğlu, 2000'den akt. Akgöz vd., 2016: 398) turistik ürünü oluşturan faktörleri üç temel başlık altında değerlendirmektedir:

- Turist alan bir yörenin veya ülkenin kendi içindeki değerleri (doğa, tarih, kültür vb.)

- Turistin tatil boyunca yararlandığı hizmetleri veren işletmeler (otel, acentalar vb.)

- Turistin turizm faaliyeti içerisinde yaptı̆̆ geziler (taşımacılık işletmeleri)

Van otlu peynirinin hikâyesinin turistik bir ürün olarak sunulabilmesi noktasında gerekli unsurlar ele alındığında öncelikle sunulması düşünülen hikayesinin bir turistik ürünün taşıması gereken en önemli özellik olan yöreye özgü gelenek, görenek, ortak bellek, tarihsel süreklilik, paylaşılan deneyim gibi somut olmayan kültürel değerleri üretim sürecinin her aşamasında farklı boyutları ile taşıdığı görülmektedir. Ayrıca alternatif turizme özellikle yiyecek ve deneyimleme turizmine artan ilgi sunulacak ürünün çekicilik unsurunu da arttırmaktadır. Turistik ürünlerin diğer önemli unsurları olan üretildiği yerde tüketilmesi zorunluluğu nedeniyle ziyaretçilerin peynirin üretiminin yapıldığı geleneksel üretim alanları olan yaylalarda çadırlar ve köylerde ise geleneksel mekanlar mevcut olmakla beraber mekan kullanımlarının ziyaretçiler için yeniden planlanması ve aslına uygun iyileştirilmesi gerekecektir. Ziyaretçilerin mal veya hizmetin üretildiği yere gitme zorunluluğu nedeniyle ulaşılabilirlik de önemli bir unsur olarak karşımıza çıkmaktadır. Zaman ve maliyet açısından ürünün ulaşılabilir olduğu düşünülmektedir. Turizm olanakları değerlendirildiğinde ise hem kente ulaşım hem de tur ya da servis hizmetlerini sağlayabilecek yeterli sayıda işletme mevcuttur. Kentin ziyaret edilecek bölgeleri için de ulaşım altyapısı yeterlidir. Peynir üretiminin deneyimleneceği mekânların aynı zamanda konaklama hizmeti verecek şekilde bütünleşik bir yapıya geçmesi yakın gelecekte olanaklı görülmektedir ancak günümüzde ürünün deneyimlenmesi sonrası konaklama hizmeti kent merkezinde sunulabilecektir. Kent ayrıca eğlence, yeme-içme hizmetleri anlamında çeşitliliğe sahiptir.

\section{Yöntem}

\subsection{Araştırma Sahası}

Van’ın Başkale ilçesinin Orta Yol köyü, Çatak ilçesinin Görentaş köyü Badılhali yaylası, Özalp ilçesinin Aşağı Molla Hasan Mahallesi (köyü), Gürpınar ilçesinin Yol Düştü Mahallesi (köyü) arazi çalışması için belirlenmiştir. Belirlenen araştırma sahaları, bölgenin coğrafi/iklim şartları nedeniyle geleneksel olarak peynir yapımına başlanan 2019 yılının Nisan ayından Ağustos ayı sonlarına kadar devam eden süre içerisinde çeşitli zamanlarda ziyaret edilmiştir. Bu kapsamda özellikle bölgede peynir turizminin yapılıp yapılmayacağına yönelik arazi gözlemleri yapılmıştır (Şekil 1). 

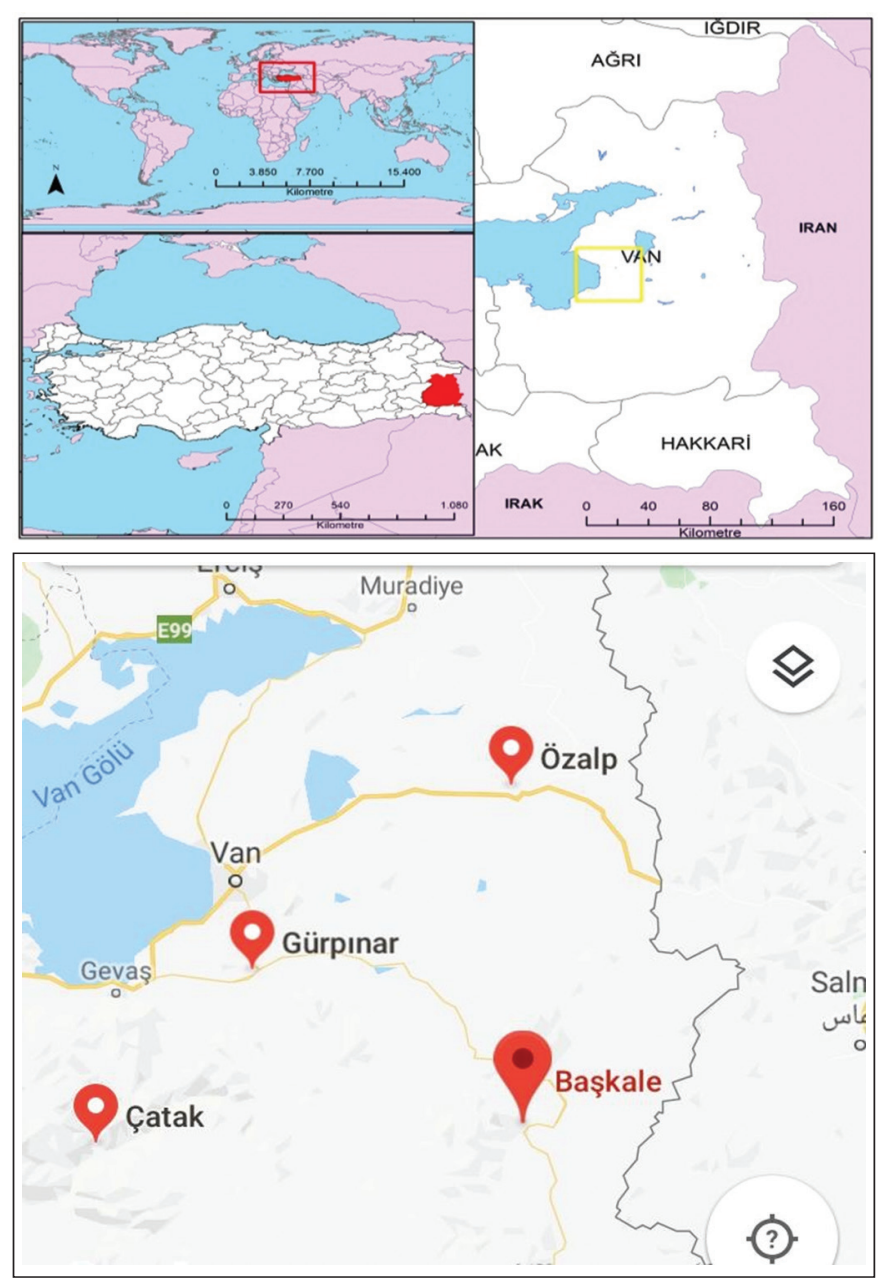

Şekil 1. Van ili lokasyon haritası ve ana peynir üretim sahaları

Figure 1. A location map of the Van region and its major cheese-making fields

\subsection{Araştırma Sahasının Turizm Bağlamında Tarihi ve Kültürel} Özellikleri

Van ili doğal, tarihi ve kültürel özellikleriyle Türkiye'de Doğu Anadolu bölgesinde önemli turizm merkezlerinden biri olabilecek potansiyele sahiptir. Kent geçmişten günümüze Urartu, Asur, Selçuklu, Osmanlı gibi birçok medeniyete ev sahipliği yapmıştır. Tarihi İpek Yolu güzergâhında bulunması nedeniyle geçmişte olduğu gibi jeo-politik önemini korumaktadır. İran, Irak ve Ermenistan gibi ülkelere sınır komşusu olması, ilin uluslararası etkileşim yaratan bir sınır mekânı olmasını sağlamaktadır. Kent bu köklü yaşanmışlıkları ile birçok tarihi ve kültürel varlığa ev sahipliği yapmaktadır. Bunların başında Akdamar Adasında bulunan Ermeni mimarisi örneği Surp Haç Kilisesi, Başkale ilçesinde bulunan Hristiyanlığın önemli dini yapılarından St. Bartholomeus Kilisesi, Gevaş ilçesinde bulunan Sn. Thomas Kilisesi, Selçuklu Dönemine ait Halime Hatun Kümbeti, Edremit Kalesi, Kalecik Urartu Gözlem Alanı ve Nekropolü, Mehr Kapı, Yedi Kilise, Tarihi Van Evleri, Urartular döneminden kalma Van Kalesi, Menua (Şamram) Sulama Kanalı, Urartu Yazıtları gibi pek çok kültürel ve tarihi varlık yer almaktadır (Cihangir \& Şeremet, 2020: 51). Flamingo kuşlarının konaklama alanı olan Erçek Gölü ve Van Gölü'nün sahil kesimleri kuş gözlemi yapılabilecek birçok sulak alan içermektedir. Van Gölü’nde ayrıca eşsiz mikrobiyalitlerin görülebildiği yüksek irtifa tüplü dalış sporunun yanında pek çok su sporu yapılabilmektedir.
Başkale Akçalı Travertenleri, Muradiye Şelalesi, Bendi Mahi çayı üzerinde yumurtalama alanlarına ulaşmak için akıntıya ters yüzen İnci Kefallerinin izlenmesi ve koruma altındaki Van kedileri görülebilecek diğer güzellikleridir. Çok özel bir gümüşçülük sanatı olan "savat" ve "kilim" dokuma kültürü önemli kültürel turizm öğeleri içerisinde yer almaktadır. Açık hava müzesi niteliğindeki Çavuştepe ve Ayanis kazıları ise halen devam etmekte olup geçmişten itibaren bölgeden çıkarılan eserler bugün Van Müzesinde sergilenmektedir.

$\mathrm{Bu}$ çalışmanın temel konusunu oluşturan yiyecek ve içecek tu-rizmi açısından bakıldığında Van kentinin önemli bir mutfağı bulunmaktadır. Bu çerçevede, Van'ın özellikle küçükbaş üretimine bağlı olarak gelişen et ve süt üretimi nedeniyle, birçok yerel yemeğin özellikle süt ürünleri, bölgede yetişen doğal otlar ve yörede yetişen küçükbaş ve büyük baş hayvanların etlerinin kullanılmasıyla üretildiği görülmektedir. Bu yöresel yemekler arasında ayran aşı (yöresel otlar, yoğurt kullanılarak yapılmaktadır); keledoş (yöresel etler, yerel otlar, bulgur); yöresel kebaplar (küçükbaş ve büyükbaş hayvan eti); sengeser (mercimek ve yöresel otlar); kavurma (küçükbaş hayvan eti); Tuzlu Van Balığı (İnci Kefali); helise (buğday, küçükbaş hayvan eti, tereyağ).

Günümüzde geleneksel olarak sürdürülen Van kahvaltısı geleneksel ürünlerin bir arada sunulmasıyla oluşan önemli bir diğer gastronomi kültürüdür ve yerel halk için kentin markalaşma çalışmalarında önemli bir kültürel değer olarak algı-lanmaktadır (Şehribanoğlu, Cihangir, Levendoğlu \& Saydan, 2017: 572). Kent merkezinde Van kahvaltısının sunulduğu "Kahvaltıcılar Sokağı" ve Edremit ilçesinde de Van Gölü manzaralı sadece kahvaltı hizmeti veren mekanlar bulunmaktadır (Cihangir \& Şeremet, 2020: 51). Van kahvaltısı; Van otlu peyniri, cacık, tereyağ, kaymak (manda veya inek kaymağı), bal (kara-kovan balı yörede üretilen), murtuğa, Van kavut, Van gül reçeli, Van çöreği, kavurmalı yumurta, menemen, sahanda yumurta veya sucuklu yumurta gibi yumurta ile hazırlanan yiyecek çe-şitlerini içermelidir. Kahvaltı tercihe bağlı olarak sıcak süt ile servis edilebilmektedir. Van kahvaltısı(mahreç-2020), Van otlu peyniri (menşe-2018), Van gül reçeli (menşe-2020), murtuğa (mahreç-2017), Van kavut (mahreç-2018) coğrafi işaretli ürünlerdir (TÜRKPATENT: 2020).

\subsection{Araştırma Tasarımı}

Araştırma iki aşamalı saha çalışması olarak yürütülmüştür. Ayrıca, saha çalışmaları öncesinde ve beraberinde literatür çalışması yapılmıştır. Araştırmanın sahada yürütülen her iki aşamasında yerel gelenekler ve kültürel mirasın bölgenin koşulları ile birlikte analizine yönelik derinlemesine bağlamsal veriler sağlayabilmesi için nitel araştırma yönteminde durum çalışması yorumlayıcı bir paradigma ile yürütülmüştür. Nitel araştırma tasarımı, çeşitli sosyal ortamları ve bu ortamlarda yaşayan grupları veya bireyleri inceleyerek doğru yanıtları arar. Nitel teknikler, araştırmacıların başkalarının anlayışlarını ve algılarını paylaşmalarına ve insanların günlük yaşamlarını nasıl yapılandırdıklarını ve onlara nasıl anlam verdiğini keşfetmelerine olanak tanır. Nitel araştırmalar, insanların kendilerini ve or- 
tamlarını nasıl düzenlediklerini ve bu ortamlarda yaşayanların semboller, ritüeller, sosyal yapılar, sosyal roller vb. aracılığıyla çevrelerini nasıl anlamlandırdığı ile daha çok ilgilidirler (Lune \& Berg, 2017: 15-16). Durum çalışmaları bir kültürel grup, köy veya aile gibi sosyal bir olgunun çevreyle ilgili gelişim faktörlerini vurgulamak amacıyla derinlemesine incelenmesi ve yoğun bir analizidir. Durum çalışmaları tanımlayıcı veya açıklayıcı içgörüler sağlayabilir. Ayrıca olayın bütünlüğünü ve birliğini korumayı amaçlayan bütüncül bir odağa sahiptir. Durum çaIışmaları, tekli veya çoklu vakaları ve çeşitli analiz düzeylerini içerebilir. Araştırma tasarımları, tek veya çok odaklı durum ve süreç sorgulamalarının ihtiyaçlarına bağlı olarak değişir (Babbie, 2016: 302; Flyvbjerg, 2011: 301; Jupp, 2006: 20; Creswell, 2014: 14; Yin, 2014: 5; Şeremet \& Alaeddinoğlu, 2016: 360; Denzin \& Lincoln, 2018: 552). Durumlar oldukça özeldir ve incelenen durum belirli bir grup insandan ziyade belirli bir süre olabilir. (Babbie, 2016: 302). Durum çalışmaları tipik olarak dokümantasyon, arşiv kayıtları, görüşmeler, doğrudan gözlemler, katılımcı gözlemi gibi veri toplama yöntemlerini birleştirir. Araştırmacılar, uzun bir süre boyunca çeşitli veri toplama prosedürlerini kullanarak ayrıntılı bilgi toplar (Eisenhardt, 1989: 534; Stake, 2006: 1; Yin, 2014: 105). Durum çalışmaları son yıllarda turizm çalışmalarında giderek artan bir şekilde kullanılan değerli bir araştırma stratejisi olarak kabul edilmektedir (Xiao \& Smith, 2006: 742; Yanık, 2015: 255).

\subsection{Veri Toplama ve Çözümlenmesi}

Araştırmanın birinci aşaması bu çalışmanın amacına ve araştırma sorularına temel veri sağlaması amacıyla ön araştırma olarak yürütülmüştür. Bu aşamada katılımcı olmayan gözlem tekniği ile Van otlu peynirinin yerel üreticiler tarafından sürdürülen üretim süreçleri ve bölgenin peynir turizmi için potansiyeline yönelik arazi gözlemleri yapılmıştır. Bu amaçla öncelikle Van'ın peynir üretiminde öne çıkan sahaların belirlenmesi için Van otlu peynirinin pazarlanmasında önemli bir mekân olan Tarihi Van Peynirciler Çarşısı'nda bulunan 16 esnafla yarı yapılandırılmış yüz yüze görüşmeler yapılmıştır (2019 yılı Mart-Nisan ayları) Veri toplama esnasında veri tekrarlarının başlaması nedeni ile veri toplama açısından doyuma ulaşıldığı düşünülerek gözleme son verilmiştir. Görüşmeler, 30-40 dakika aralığında sürmüş ve katılımcıların bilgisi dâhilinde veri kaybı olmaması açısından ses kayıt cihazları ile kayıt altına alınmış ve çözümlenerek saha çalışması yapılacak ilçeler/köyler (mahalleler) belirlenmiştir. Ayrıca, Van Aşçılar ve Pastacılar Derneği (VANPAD)'in ve Tüm Restoranlar ve Turizmciler Derneği (TÜRES)'in Van Şubesi yönetici ve üyelerinin görüşleri her iki aşamada da alınmıştır Katılımcıların kodlaması şu şekildedir: (VP1), (TR1), (TR2).

Araştırmanın ikinci aşaması bu çalışmanın amacına yönelik olarak planlanmıştır. Van otlu peynirinin hikayesinin-çiftlikler, köy evleri gibi yöresel mekanlar ya da yaylalarda sürdürülen geleneksel üretiminin deneyimlenmesinin iyi uygulama örneklerinde olduğu gibi turistik bir ürün niteliğinde pazarlanmasına sektörün yaklaşımı ve tematik rotalarda yer almasına yaklaşımları ve rota önerileri bu aşamada araştırımıştır. Bu amaçla veri toplama sürecinde araştırma ekibi TÜRSAB-DAB (Türkiye Seyahat Acentaları Birliği Doğu Anadolu Bölgesi) üyesi gönüllü seyahat acenteleri ile yüz yüze yarı-yapılandırılmış görüşmeler yürütmüştür (2019 EylülAralık). Görüşmeler ile bölgede tur hizmeti veren 5 farklı seyahat acente sahip ve profesyonel turist rehberi olarak ŞURO (Şanlıurfa Turist Rehberliği Odası) üyesi rehberlerin görüş ve önerileri alınmıştır. Görüşmeler 40-50 dakika aralığında gerçekleşmiştir. Bu görüşmelerde alınan notlar ve araştırmacıların Van ve yakın çevresinde yapmış oldukları saha çalışmaları sonucunda elde etmiş oldukları veriler sentezlenerek potansiyel peynir turizm rotalarının oluşturulması amacı güdülmüştür. Bu aşamada Google Map programı aracılığıyla peynir üretim deneyimini de içeren rotalara yönelik haritalar çizilmiştir. Çizilen haritalar Van havzasında ve bölge genelinde ulusal ve uluslararası turlar planlayıp rehberlik hizmeti veren profesyonel turist rehberi olarak ŞURO üyesi olan ve aynı zamanda TÜRSAB üyesi seyahat acentesi sahibi olan katılımcı (R.1) ile yürütülen derinlemesine yüz yüze görüşmede tekrar ele alınarak son hali ile düzenlenmiştir. Görüşme, 90 dakika sürmüş ve katılımcının bilgisi dâhilinde ses kayıt cihazları ile kayıt altına alınmış ve çözümlenerek belirtilen tur rotalarına ilişkin görüşler yazılı olarak kayıt altına alınarak haritalar üzerinde güncellemeler yapılmıştır. Katılımcıların kodlaması şu şekildedir: TÜRSAB üyesi acenteler (A.1), (A.2), (A.3), (A.4), (A.5) ve Rehberler; (R.1), (R.2), (R.3).

\subsubsection{Verilerin analizi}

Verilerin analizlerinde elde edilen veriler yorumsayııılık yaklaşımı çerçevesinde betimsel analiz ile araştırmanın temalarına yönelik olarak değerlendirilmiştir. Betimsel analizde amaç elde edilen verilerin düzenlenmesi ve yorumlanması araştırma sonuçlarının anlaşılır şekilde sunulmasıdır (Gürbüz \& Şahin, 2014: 413). Betimleme, ayrıntılı arka plan bilgisi sağlar, bir olay hakkında bilgi verir ve kişilerin bu olayı nasıl deneyimlediğini anlatır (Corbin \& Strauss, 2015: 33). Veri analizi, temel olarak araştırma sorularınızı cevaplamak için kullanılan süreçtir (Merriam \& Tisdell, 2016: 203). Araştırmacı elde ettiği veriyi daha önceki aşamalarda belirlediği araştırma soruları, kavramsal çerçeve, görüşmeler ve katılımcı olmayan gözlemlerde yer alan boyutlar göz önünde tutularak oluşturulan veri analiz çerçevesi ve temalara göre özetler ve yorumlar (Gürbüz \& Şahin, 2014: 271; Yıldırım \& Şimşek, 2018: 239). Temalar/kategoriler veya bulgular araştırma sorularına yanıt verdiğinden temaların/kategorilerin adı araştırmanın amacına ve yönelimine uyumlu olmalıdır (Merriam \& Tisdell, 2016: 211-212). Temalar kavramsal çerçeveden ve araştırma sorularından ortaya çıkabilir (Veal, 2018: 462).

Araştırmacılar çözümlenmiş verileri bağımsız olarak okuyarak değerlendirerek verileri ana temalar ve kategoriler çerçevesinde tümden gelimsel olarak indirgeyerek verilerin hangi tema ve kategorilerin altında düzenleneceğini belirlemişlerdir. Araştırmacıların oluşturdukları temalar ve kategorilere ilişkin veriler karşılaştırarak ve görüş birliğine varılmıştır. Gerçekte, kategoriler araştırma sorularının cevaplarıdır. Bu anlamda bu aşamada belirlenen kategorilerin kapsamlı olmasına, birbirini dışlamasına ve belirli bir veri biriminin yalnızca bir kategori altında yer alacak şekilde belirlenmesine dikkat edilmiştir (Merriam \& Tisdell, 2016: 212). 
Çalışmanın veri analizi sürecinde araştırma soruları ve kavramsal çerçeve göz önüne alınarak temalar ve kategoriler oluşturulmuştur (Gürbüz \& Şahin, 2014: 413; Yıldırım \& Şimşek, 2018: 239). Araştırmanın birinci aşamasına ilişkin analizler ve elde edilen bulgular araştırmanın ikinci aşamasında görüşme sorularının geliştirilmesinde kullanılmıştır (Merriam \& Tisdell, 2016: 191). Çalışmanın her iki aşamasına ilişkin temalar ve bulgular oluşturulmuş ancak ilk aşamaya ilişkin bulgular bu çalışma için baz olarak değerlendirildiği için bu çalışma kapsamında burada sunulmamıştır (Tablo 1) (Bkz. Cihangir, Demirhan \& Şeremet, 2020). Son aşamada elde edilen bu temalar ve kategoriler ile ilişkili yanıtlar yorumlanmış ve katılımcıların görüşlerinden doğrudan alıntılara da yer verilmiştir.

Tablo 1. Araştırmaya ilişkin tema ve kategoriler

Table 1. Themes and categories of qualitative research's outcomes

\begin{tabular}{|c|c|c|}
\hline Temalar & Kategoriler & Alt Kategoriler \\
\hline Turizm & $\begin{array}{l}\text { Turistik Ürün } \\
\text { Alternatif Turizm } \\
\text { Yiyecek Turizmi } \\
\text { Peynir Turizmi } \\
\text { Tematik Kültür } \\
\text { Rotası }\end{array}$ & $\begin{array}{l}\text { Van Otlu Peynirinin Turistik Ürün } \\
\text { Olarak Pazarlanma Potansiyeli, } \\
\text { Peynir Turizmi Bağlamında İlgili } \\
\text { Sektörlerin Van Otlu Peynirinin } \\
\text { Deneyimlenmesine Yaklaşımı, } \\
\text { Van Otlu Peyniri Üretimi Yapılan } \\
\text { Geleneksel Yöresel Mekânların } \\
\text { Tematik/Kültür Rotalarında Yer } \\
\text { Alması }\end{array}$ \\
\hline Peynir* & Van Otlu Peyniri & $\begin{array}{l}\text { Van Otlu Peyniri Geleneksel } \\
\text { Üretim Sürecinin Hikâyesi, } \\
\text { Günümüzde Van Otlu Peyniri } \\
\text { Üretiminde Devam Eden } \\
\text { Geleneksel Yöntemler, } \\
\text { Günümüzde Van Otlu Peyniri } \\
\text { Üretiminde Kaybolmuş } \\
\text { Geleneksel Yöntemler }\end{array}$ \\
\hline Yerel Üretici** & $\begin{array}{l}\text { Kadın } \\
\text { Erkek }\end{array}$ & $\begin{array}{l}\text { Kırsal Kadının Güçlendirilmesi, } \\
\text { Erkeklerin Üretim/Pazarlamada } \\
\text { Rolü ve Ekonomik Güç İlişkisi }\end{array}$ \\
\hline
\end{tabular}

* Peynir teması ile ilgili bulgulara bu çalışma kapsamında yer verilmemiştir.

** Yerel üretici teması ile ilgili bulgulara bu çalışma kapsamında yer verilmemiştir.

\subsubsection{Geçerlilik/Güvenirlilik}

Geçerlilik ve güvenilirlik nitel paradigmada güvenilirlik, titizlik ve kalite olarak kavramsallaştırılmaktadır (Golafshani, 2003: 604). Nitel araştırmada araştırmacı araçtır ve araştırmanın güvenilirliği büyük ölçüde saha çalışmasını yapan kişinin becerisine, yeterliliğine, titizliğine ve hayatında olup bitenler ile dikkat dağıtıcı olabilecek şeylere bağlıdır (Patton, 2014: 67). Araş-tırmacı ile katılımcılar arasındaki etkileşimin doğası, verilerin çeşitlendirilmesi, algıların yorumlanması, zengin ve yoğun bir betimleme geçerlilik ve güvenilirlik için önemli unsurlardır (Merriam \& Tisdell, 2016:191-192).

Çalışmanın yapı geçerliliğin Yin (2017: 80) artırılması için aşağıdaki ölçütler göz önüne alınmıştır;

1. Yüz yüze görüşmeler (her iki aşamada), katılımcı olmayan

gözlem ve katılımcı gözlem(birinci aşamada-ikinci yazar katılımcı gözlemci aynı zamanda), uzman görüşü(her iki aşamada) gibi birden fazla veri kaynağı ve araştırmacı veri toplama sürecinde kullanılmıştır (Flick, 2018: 779; Denzin, 1978: 295 ).
2. Toplanan verilere ilişkin bir kanıt zincirinin oluşturulmuştur. Çalışma sonucu ortaya konulan bulgular (alıntılar, atıflar), yöntem/veri toplama ve çözümlenmesi bölümünde sunulan araştırma verilerine ilişkin veri tabanı (ses kayıtları, video kayıtları, yazılı saha notları, literatür taraması), araştırma veri tabanında yer alan kanıtlara yapılan alıntılar, atıflar; durum çalışmasına ilişkin bir çalışma planı hazırlanmış ve araştırma soruları çerçevesinde yarı-yapılandırılmış soru formları hazırlanmıştır.

3. Araştırmanın ana amacına(ikinci aşamada) yönelik hazırlanan rotalar veri toplanan kilit bilgi kaynakları tarafindan gözden geçirilmiştir. Sonuçları veri toplama sürecinde kendisinden veri alınan uzman bir rehbere okutularak görüşü alınmıştır.

Güvenilirlik, çalışmaların ne kadar çoğaltılabileceğini ifade eder. Aynı yöntemleri kullanan bir araştırmacının, önceki bir çalışmanın sonuçlarıyla aynı sonuçları elde etmesini gerektirir (LeCompte \& Goetz, 1982: 35). Dış güvenirlik, bağımsız araştırmacıların araştırma sonuçlarını benzer ortamlarda aynı veya benzer şekilde elde edip edemeyeceğine, iç güvenirlik ise diğer araştırmacıların aynı verileri kullanarak araştırmacının sonuçlarına ulaşma derecesini ifade eder (LeCompte \& Goetz, 1982: 32). Ancak durum çalışmalarında araştırmanın tam olarak kopyalanması imkansızdır, ancak bir dizi durum çalışmasından elde edilen kanıtların birikimi, bir durum çalışması araştırma programının bulguları ve diğer kanıtlar etrafında bir fikir birliği oluşturabilir (Veal, 2018: 400). Bu nedenle çalışmanın güvenirliği noktasında ele alındığında durum çalışması olması nedeniyle aynısının kopyalanması olanaklı olmayacağı ancak benzer çalışmalarda fikir birliği oluşturacağı söylenebilir.

\section{Bulgular}

Araştırma sorularına ilişkin bulgu ve yorumlar aşağıda sunulmaktadır.

4.1. Van Otlu Peynirinin Geleneksel Üretim Hikayesinin Alternatif Turizm Bağlamında Değerlendirilmesine Turizm Sektörünün Yaklaşımı

Turizm sektörünün ziyaretçileri belirli bir destinasyona yönlendirme gücü anlamında önemli paydaşlarından olan seyahat acenteleri ve profesyonel tur rehberleri ile VANPAD ve TÜRES üyeleri olan aşçılara Van otlu peynirinin hikayesinin alternatif turizm/yiyecek turizmi/deneyim turizmi kapsamında ele alınarak değerlendirilmesi hakkında görüşleri sorulduğunda, kentin bugün için genel anlamda somut ve somut olmayan kültürel mirasının, coğrafi ve doğal zenginliklerinin turizm ürününe yeterince dönüştürülemediğini, planlama, tanıtım ve pazarlama faaliyetlerinin bütünsel bir yaklaşımla yürütülmediğini belirtmişleridir. $\mathrm{Bu}$ bağlamda kentin geleneksel yerel yiyeceği olan Van otlu peynirinin geleneksel üretim sürecine ilişkin hikayesinin de bugüne kadar turistik ürün olarak değerlendirilemediğini, köylerde/yaylarda geleneksel peynir üretiminin deneyimlenebileceği peynir çiftlikleri/ mekanları oluşturulabilirse rotalar içerisinde yer verilerek kentin önemli bir turizm ürünü kazanabileceğini ifade etmişlerdir. 
“Kars Boğatepe'yi görüp hayıflanmamak mümkün değil. 150 yıllık hikâyesi olan bir yerde bu kadar başarı elde edildi. 3000 yıllık bir hikâyenin ortaya çıkarılması ve rota haline gelmesi hem sektörü hem de sektörün paydaşları olan ve birebir muhatabı olan köylüler için müthiş bir paylaşım olacak" (A1-R1)

"Evet, bizim aslında yöresel yemeklerimiz gerçekten çoktur. Mesela peynirin gömülme olayı turistlerin çok ilgisini çeker... Kültür rotalarının içinde olabilir. 'Culinary' turizm için bu konuda çalışma yapacağız. Van'ın da içinde olduğu bölgeyi kapsayan tur yapacağız. Dış pazara yapacağız" (A2-R2)

"Bu işin başlaması için bir kıvılcım gerekiyor. O kıvılcım nedir? Bir turizm sezonu içerisinde 3-4 defa bu tür organizasyon ya-pılır ve görsel olarak ya da yazılı olarak basında yer alırsa..." (A3-R3)

Görüşmecilere, Van otlu peyniri hikayesinin turistik ürün olarak Van kültür rotalarında yer almasının Van turizmi üzerinde etkileri neler olur? sorusu yöneltildiğinde kente 1990 'ı yıllarda ağırlıklı olarak kültür ve diaspora turizmi için Avrupa ve Amerika'dan turistlerin geldiğini, son yıllarda ise ağılıklı olarak sınır komşusu olmasıyla nedeni ile İranlı turistlerin öncelikle alış-veriş amacıyla olmak üzere eğlence ve kültürel faaliyetler için geldiklerini belirtmişlerdir. İstatiksel veriler incelendiğinde saha görüşmelerini doğrular sonuçlar karşımıza çıkmaktadır. 1990'li yıllarda Türkiye'yi ziyaret eden her bin turistten 17'sinin ziyaret ettiği Van, bugün her bin turistten sadece 1,5'ini çekebilmektedir (DAKA, 2019: 11). Buna karşılık, son yıllarda bölgeye yönelik ilginin iç turizmde artması nedeniyle düzenlenen Doğu Anadolu ve Van Gölü havzası kültür turlarında Van önemli bir destinasyon olarak yer almaya başlamıştır. Ancak, saha araştırmalarında görüşülen TÜRSAB üyesi acente ve rehberleri, turlar kapsamında Van'a ayrılan gezi sürelerinin genellikle bir en fazla iki günü geçmediğini ve geceleme sayılarının ise ortalama iki gün ile sınırlı olduğunu belirtmişlerdir. Yine görüşmeler önemle üzerinde durulan diğer nokta ise Van'ın turizm potansiyelinin en az üç hatta dört-beş günlük bir tur programı için fazlasıyla yeterli olabileceği ancak kentin tarihi ve kültürel mirasının, coğrafi değerlerinin ve gastronomisinin turistik ürün olarak yeterince kullanılmadığına vurgu yapmışlardır.

"Peynirin hazırlanması, salamura yapılması... Saklama toprağından satış ofisine gelene kadar bütün süreci göstermek isterim" (A4, A5)

"Peynir çiftliğinde 3 saat de harcanır 5 saat de. Hollanda'da deneyimledik. Sabah 7'de karanlıkta otelden aldılar. Öğlen yemeğinde ayrıldık" (A4, A5)

"Mayısta başlayıp ağustosa kadar yayla ziyaretleri olabilir." (A4)

4.2. Van Otlu Peynirinin Turistik Ürün Olarak Van Kültür Rotalarında Yer Almasına İlişkin Bulgular.

Van otlu peynirinin deneyimlenmesine yönelik olarak oluşturulacak geleneksel mekanlara, çiftliklere ve yayla ziya- retlerine otalarda yer verilebilir mi? sorusuna Van'ın sahip olduğu coğrafi, doğal ve kültürel değerlerinin yerel lezzetler ile bütünleşik olarak ziyaretçilere sunulmasının kentin turizmine çok önemli ile katkı sağlayacağını ifade etmişlerdir.

"Boğatepe'ye Mayıs ayında gittik 25.000 turist gelmiş. Van gibi bir yere çok daha fazlasını çekebiliriz...." (TR2)

"Turizm sektörü pastası büyüktür. Bütün dünyadır pasta, yeni destinasyonlar açmak gerekiyor. Bizim turizm ürünü sorunumuz yok. Bizim turizm ürünlerini ön plana çıkarma sorunumuz var." (A2-R2)

"Peynir için farklı yerlerdeki farklı köyler olmalı. Görentaş olmalı. Çaldıran olabileceğini düşünüyorum. Gevaş'ın köyleri de... Özalp ve Saray birlikte değerlendirilmeli." (A3-R3)

$\mathrm{Bu}$ anlamda görüşleri alınan VANPAD Derneği ve TÜRES Derneği yönetici ve aşçları ise kentin ve bölgenin unutulmaya yüz tutan geleneksel lezzetlerinin son zamanlarda yürütülen bireysel ve kurumsal destekli araştırmalar sonucunda yeniden Van mutfağına kazandırılmaya başlandığını ancak bu çalışmaların henüz istenilen düzeyde olmadığını ve böyle bir rota çalışmasının yapılarak gerçekleşmesi halinde diğer yerel lezzetlerinde tanıtılmasında olumlu katkı sağlayacağını ve rol oynayacağını belirtmişlerdir. Bu anlamda rotalarda yer alacak çiftlik ziyaretlerinde verilecek olan geleneksel Van kahvaltısı ve yöresel öğlen yada akşam yemeklerinin doğal olarak süreci destekleyeceğini ve farklı turizm ürünlerinin deneyimlenmesi içinde fırsat yaratacağını düşünmektedirler.

"Şu an gastronomi için turist gelmiyor... Iyi bir tanıtım ve alt yapımızın sağlam olması gerekiyor... Ama etkileyebileceğimiz iyi ürünlerimiz var... Potansiyelimizi artırabiliriz" (TR1).

"Van'ın tarihi bölgelerini kapsayan bir gastronomi turu daha iyi olur. Geceleme sayısı yüzde yüz artar... Eğer bu rotalar oluşursa..." (TR2).

Bu rotalarda peynirin turistik ürün olarak yer almasının Van turizmine etkisi ile ilgili görüşleri sorulduğunda, özellikle yurt-dışında tematik peynir rotalarının çok önemli bir pazara sahip olduğu vurgulanarak bu anlamda Van'ın sahip olduğu doğal ve kültürel değerleri ile peynirin üretim hikayesinin birlikte yer alacağı rotaların Van'ın tek başına bir destinasyon olarak pazarlanmasında önemli bir fark yaratacağını belirtmişlerdir.

"Son 2-3 yıldır sezon Şubat sonuna geldi. Sezon ikiye ayrıldı... Doğu Ekspresi patlayınca bize de etkisi oldu. Kışın da geliyorlar... Şu anda 12 ay turist alıyor... Ama Van tek almıyor Kars'la beraber alıyor" (A3-R3)

"Bu oluşturulacak rotalar ile ekstra Van'da en az 2 gece konaklama yaratır" (A1-R1) 
"Van içinden ziyade Van gölünün kenarında bir köy olabilir. Gerçek anlamda köy olabilir. İşin içine katılabilir. Bir sürü acenteden talepler aldım. Özellikle Avrupa'ı acentelerden." (A2-R2)

"Ben önümüzdeki dönemde daha özel gruplar olacağını düşünüyorum. 7-8 kişilik. Bizim işletme olarak böyle bir kitlemiz var. Ama hedef kitle olarak butik turlar ile bir köy evinde bir gece yatırmak, peynirin yapılma süreci, yumurtayı kümesten, domatesi, bostandan kendi alabileceği bir turizm çeşidi bana uygulanabilir geliyor." (A3-R3)

"Gastronomi turları ile biz Van'ı gerçekten iyi bir marka haline getirebiliriz." (VP1)

Görüşmecilere böyle bir çalışmanın sektöre katkısı olur mu? sorusu sorulduğunda çalışma ile sektöre yeni bir ürün sunulmuş olacağını ve sonuçları itibari ile aslında tüm sektörleri zincirleme etkileyeceğini belirterek bu çalışmanın yerel girişimciliği desteklemesi ile kentin ekonomisine sağlayacağı katkının yanı sıra sosyo-kültürel anlamda önemli değişimleri ateşleyeceğini belirtmişlerdir. Bu anlamda kırsalda yaşayan yerel üreticilerin ve özellikle kırsalda yaşayan kadınların yerel girişimci konumuna geçmesi ve turizm faaliyetlerinde yer alması ile kırdan kente göçün önüne geçileceği ve kırsalda yaşayanların ve özellikle ev içi ücretsiz içi olarak görülen kadınların sosyo-ekonomik olarak güçleneceği düşünülmektedir.

"Uygulamacılara, sektöre yepyeni bir ürün hazırlamış olursunuz. Diyebiliriz ki; bugüne kadar bir günlük iki günlük Van turları yapıyordunuz. Ama aslında Van'ın 6-7 günlük bir tur potansiyeli var. Van'a gelip iyi bir otel de kalıp, çok rahat bir şekilde coğrafyası, tarihi dokusu, kültürü, yerel yiyecekleri, müziği, düğünü ve insanı ile çok özel bir deneyim yaşayacağınız bir tur programı sunuyorsunuz" (A1-R1)

"Uygulamada, bizim turiste ihtiyacımız var. Biz turiste doymuş bir şehir değiliz. Kazandıklarımızı yeni destinasyonlar yaratmak için harcıyoruz, fuarlara gidiyoruz." (A3-R3)

"Sadece gastronomi olarak düşünmeyin buraya gastronomi turu için gelecek olan kişi otelde kalıyor, bara gidiyor lokantaya gidiyor, gümüşçüye uğruyor, Van kedisi için Van kedi evine gidiyor, sahillerimizi geziyor." (TR1)

\subsection{Van Otlu Peyniri Turistik Ürün Olarak Van Destinasyonu} Kültür Rotalarında Nasıl Yer Alabilir?

Sektör temsilcilerine Van otlu peynirinin hikayesinin kültür rotalarında nasıl yer alabileceği sorulduğunda Van'ı ziyarete gelen turistlerin kentin somut kültürel değerlerini ve doğal güzelliklerini tanıması kadar somut olmayan kültürel değerlerini de tanımalarının çok önemli olduğuna vurgu yapmışlardır. $\mathrm{Bu}$ anlamda nesilden nesile aktarılan geleneksel üretimi ve kendine özgü hikayesi ile Van otlu peyniri bölgenin somut olmayan önemli kültürel miraslarından biri olarak görülmektedir ve kültür rotalarında bu hikâyenin doğduğu yerlerde ziyaretçiler ile paylaşılması gerektiği düşünülmektedir.

Görüşmeciler, peynirin hikayesinin gerçekten deneyimlenebilmesi için ziyaretçilerin üretimin yapıldığı köylerde ve yaylalarda geleneksel mekanlarda ağırlanması gerektiğini, ot toplama sürecinden 'şırdan' ile yapılan geleneksel peynir mayası yapımına, çobanlar ile koyun ve keçilerin güdülmesinden 'koç-başlığı' geleneğinin izlenmesine, 'berivanlar' ile birlikte süt sağımından peynirin mayalanıp otların katılmasına, mayalanma süreci sonunda peynirin salamura veya cacık ile birlikte geleneksel küplere konularak toprağa gömülmesine kadar tüm sürecin yaşanmasının hatta kendi yaptığı peyniri taze haliyle tatmasının ve tüm bu akış içinde yöre insanın özellikle yaylada,çadırlarda peynir yaparken söylediği türkülere, halaylara sohbetlere katılmasının gerektiğini düşünmektedirler.

"Gastronomi turları ...tarihi bölgelerde kırsal kesimlerde çok daha iyi olur...Ben ot toplamaya bir grup getirdim. Ot topladı-lar sonra beraber salamura yaptık..."(VP1).

"Yazın Berivan sürecine denk getirebilirsek turları bence çok özel olacaktır"(TR2).

"Mesela peynirin gömülme olayı turistlerin çok ilgisini çeker....Kültür rotalarının içinde olabilir" (A2-R2).

\section{Van Otlu Peynir Turizmi ve Kültür Rotaları}

Peynir turizmi rotalarına ilişkin iyi uygulama örnekleri kavramsal çerçevede paylaşılmıştır. Çalışmanın bu bölümünde geleneksel peynir üretiminin deneyimlenebileceği peynir çiftliği ziyareti ve kentin önemli turistik değerleri ile oluşturulan beş farklı tek günlük rota planı hazırlanmıştır. Ayrıca istenildiğinde bir günlük rotalardan biri esas alınarak diğer günlerde kentin tarihi mekânları, doğal alanları veya kültürel varlıkları ile oluşturulacak çok günlük rotalar hazırlanabilir. Bu anlamda "3 gün 2 gece" ve "4 gün 3 gece" olacak şekilde iki örnek plan da sunulmuştur.

Bir günlük ve çok günlük rotaların alternatifli planlanmasında amaç hem bireysel hem de grup olarak gelen talepler için hazırlanacak paket turların kapsayacağı turistik ürün sayısının ve ürünlerin kombinasyonunun farklılık gösterebilmesi içindir. Turistlerin ilgi, zaman, ekonomiklik gibi farklı noktalarda farklı taleplerinin olması tur programlarında sunulacak rotaları da belirlemektedir. Bu anlamda hazırlanan rotalarda Van kentine gelen turistlerin mutlaka görmek isteyeceği tarihi ve kültürel değerlerin yanı sıra her rotanın süresi içerinde geleneksel kültürün önemli bir parçası olan Van otlu peyniri üretim deneyimine yer verilmiştir.

Rota planlama çalışmaları TÜRSAB-DAB üyesi acenteler ile birlikte yürütülmüş daha sonra yine TÜRSAB ve ŞURO üyesi olan profesyonel rehber ve bölgede uzun yıllardır tur organizasyonları yapan yerel acente sahibi katılımcısında uzman görüşü alınarak son hali verilmiştir.

Çalışmada hazırlanan rotalar ile hedeflenen; tur operatörlerine, seyahat acentelerine uygulamaya hazır rotalar sunmanın ötesinde Van otlu peynirinin hikayesinin turistik ürün olarak kullanılacağı tematik/kültür rotaları önermek suretiyle turizm yatırımcılarının ve ilgili paydaşların dikkatini Van otlu peynirine çekmek ve dolayısıyla sürdürülebilir kırsal kalkınma sürecinde bölgenin turizm potansiyelinin değerlendirilerek turizm bileşenini öne çıkaracak projelerin başlatılmasıdır. 


\subsection{Tek Günlük Kültür Rotaları}

Rota 1: Van - Yavuzlar Peri Bacaları - St.Bartholomeus Kilisesi Başkale Travertenler - Van Otlu Peynir Çiftliği

Bu rotada ilk ziyaret Vanadokya olarak adlandırılan Yavuzlar Peri Bacaları'dır. (B) ikinci durak Büyük Zap Vadisi'ne bakan bir tepe üzerinde yer alan önemli Hristiyan dini yapılarından olan St. Bartholomeus Kilisesi'dir (C noktası). Öğlen yemeği molası Başkale ilçesinde (D) verilecek ve sonrasında doğal oluşum süreci halen devam eden doğa harikası Başkale Akçalı Travertenleri (E) ziyaret edilecektir. Başkale çevresinde planlanacak peynir çiftliği ziyareti ile sonlanacak olan rota sonrası Van (A) merkeze dönüş yapılacaktır. Bu rotanın toplam uzunluğu gidiş-dönüş olarak 378+15 km (Başkale ilçesine yakın olan Örencik, Ortayol, Aşalan köylerinin çiftlik yeri olarak belirlenmesi ile değişebilir) ve bir günlük bir rotadır. Bu rota aracılığıyla, Van’ın önemli peynir üretim alanlarından biri olan Başkale'de kurulması önerilen peynir çiftliğinde peynir üretiminin deneyimlenmesini içeren ziyaret düşünülmektedir. Bu rotada çiftlik ziyareti Başkale ilçesine yakın köylerden biri olabileceği gibi travertenler bölgesinde seçilebilir. Öğlen yemeği molası ilçe yerine çiftlik evlerinde verilerek çiftlik ziyareti ile birleştirilebilir (Tablo 2) (Şekil 2) (Fotoğraf 8).
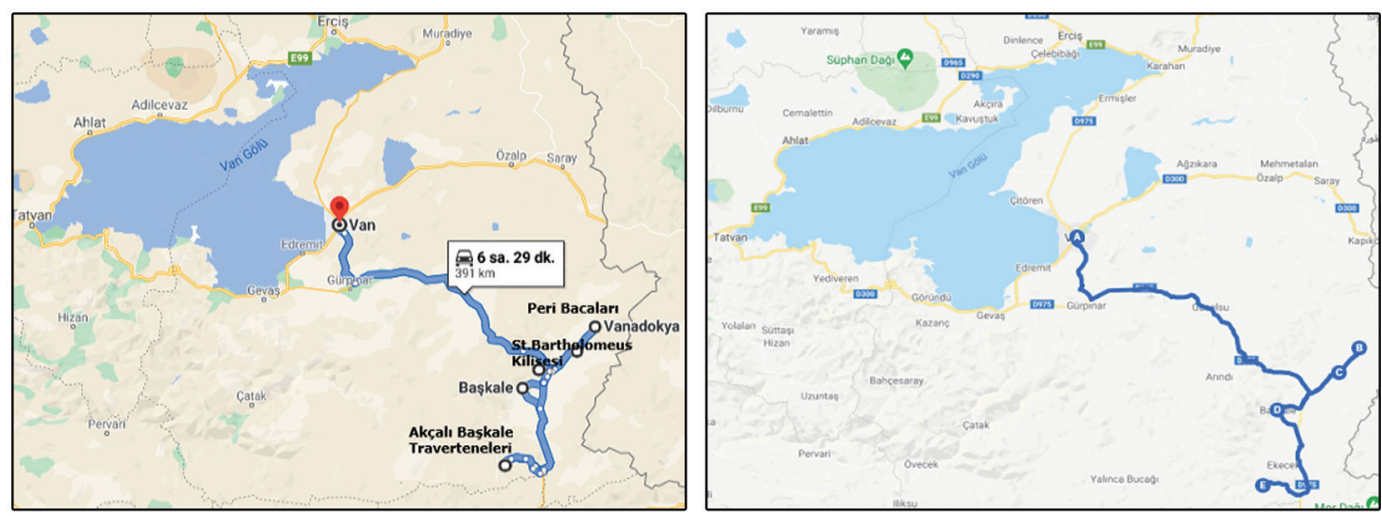

Şekil 2. Kültür rotası 1. harita üzerinde gösterimi

Figure 2. A map of cultural route 1

Tablo 2. Kültür rotası 1. planı

Table 2. The detailed plan 1 of cultural route

\begin{tabular}{|c|l|c|c|l|}
\hline Hareket Saati* & \multicolumn{1}{|c|}{ Hareket Noktası } & Mesafe (km) & Varış Saati* & \multicolumn{1}{|c|}{ Kalış Süresi (dk) Noktası } \\
\hline 08.00 & Van (A) & 135 & 09.30 & Vanadokya Yavuzlar Peri Bacaları (B) \\
\hline 10.15 & Peri Bacaları (B) & 10 & 10.30 & Albayrak/ St. Bartholomeus Kilisesi (C) \\
\hline 11.00 & St. Bartholomeus Kilisesi (C) & 24 & 11.30 & Öğlen Yemeği/ Başkale İlçesi (D) \\
\hline 12.30 & Öğlen Yemeği/ Başkale İlçesi (D) & 48 & 13.30 & Başkale Travertenler (E) \\
\hline 14.30 & Başkale Travertenler (E) & $\sim 20-30$ & 15.00 & Peynir Çiftliği Ziyareti \\
\hline 16.30 & Peynir Çiftliği & $\sim 130$ & 18.30 & Van (A) \\
\hline
\end{tabular}

* Google harita ve saha görüşmeleri ile verilen değerlerdir. hava, yol ve trafik yoğunluğu şartlarına bağlı değişebilir.
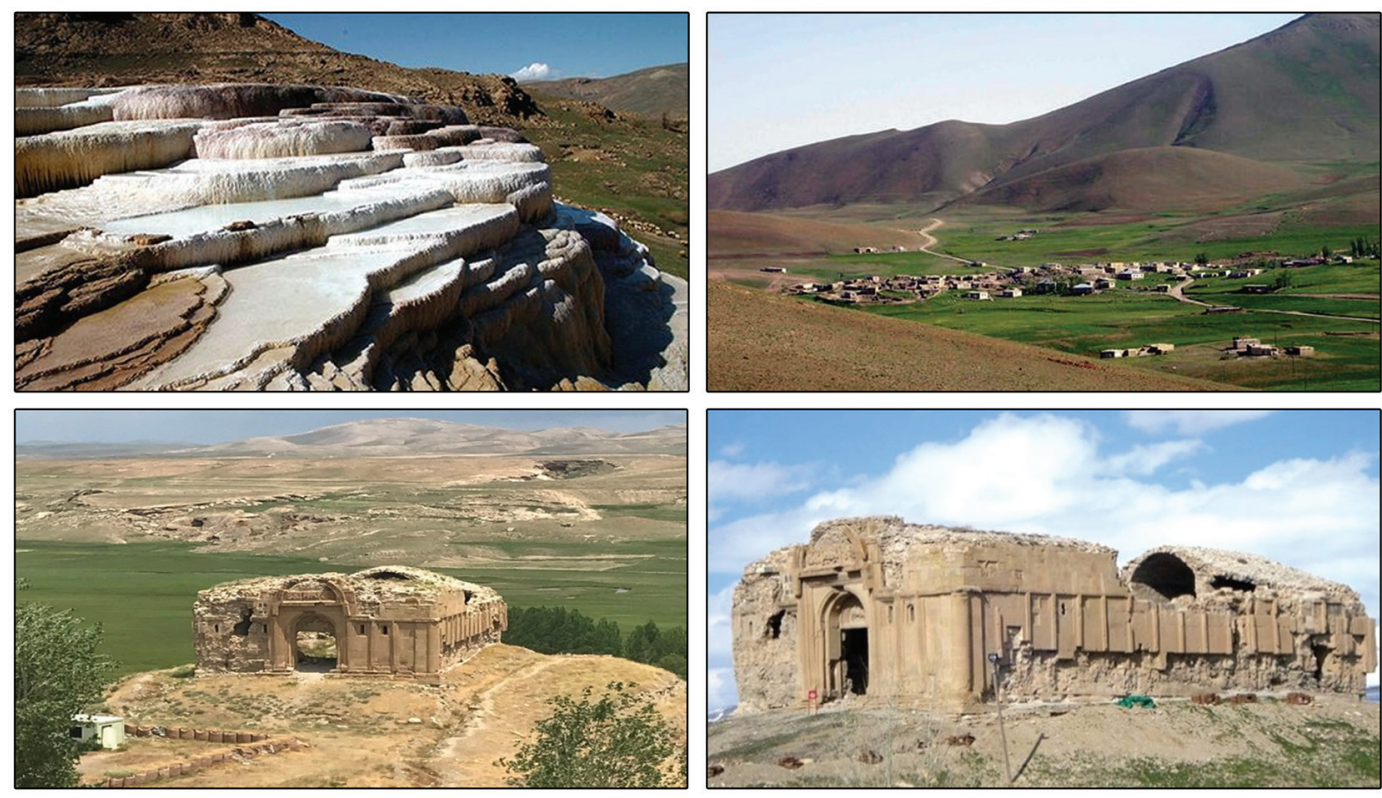

Fotoğraf 8. Kültür rotası 1.'de yer alan doğal ve kültürel değerlerden görünüm Photo 8. A view of natural and cultural assets within cultural route 1 
Rota 2: Van - Çavuştepe Kalesi - Hoşap Kalesi - Norduz Yaylası - Van Otlu Peynir Çiftliği.

Bu rota Van-Başkale karayolu güzergahında bulunan Urartu Kralı II. Sarduri tarafından Milattan Önce 750 yılında yaptırılan Çavuştepe Kalesi (B) ve sonrasında Osmanlı dönemine tarihlenen Hoşap Kalesi (C) ziyareti yapılacaktır. Gürpınar'da kentin yerel gastronomisinin tadılabileceği öğlen yemeği sonrasında Norduz Yaylasına (D) geçilecektir. Planlanan bu rotanın bir günlük olması ve Norduz Yaylasının geniş bir coğrafyayı yayılmış olması nedeniyle Gürpınar'a 33-37 km uzaklıkta olan Kuşdağı, Yoldüştü, Kırkgeçit, Örmeli köyleri plana dahil edilmiştir. Bu köylerde ziyarete açılacak çiftlikler veya geleneksel mekanlar peynir deneyimlemesi için ziyaret edilecek ve aynı zamanda dünyada sadece Van'ın Gürpınar ilçesinde yetiştirilen Norduz koyunları da görülebilecektir. Bu rotanın uzunluğu gidiş-dönüş olarak ziyaret edilmesi planlanacak köyün uzaklığına bağı olarak değişmekle beraber 149 ila 194 km araısndadır ve bir günlük rotadır. Bu rota aracılığıyla Van'ın en önemli peynir üretim alanlarından bir tanesi olan Gürpınar-Norduz Yaylasında turistik amaçlı düzenlenmiş bir peynir çiftliğinin ziyareti ve ziyaretçilerin peynir üretimini deneyimlemesi düşünülmektedir. Bu rotada yerel yiyeceklerin deneyimlenebileceği yeme ve içme mekânları da yer almaktadır. Ziyaretçiler, Gürpınar ilçesinde bulunan alabalık tesislerinde veya yerel gastronomi örneği sunan restoranlarda (Norduz Sofrası) doğal ürünleri tadabilirler (Tablo 3) (Şekil 3) (Fotoğraf 9).

Bu tur programı istenildiği takdirde 2 güne çıkarılarak Gürpınar'a 60-150 km mesafede bulunan Geçerli, Oğuldamı, Taşlıyazı, Bükeç, Beşbudak, Akdoğu, Dikbıyık, Topyıldız, Yalınca, Sıcaksu ve Geziyurt köyleri ziyaret edilebilir ve planlanacak yayla çiftlik evlerinde konaklama yapılabilir.
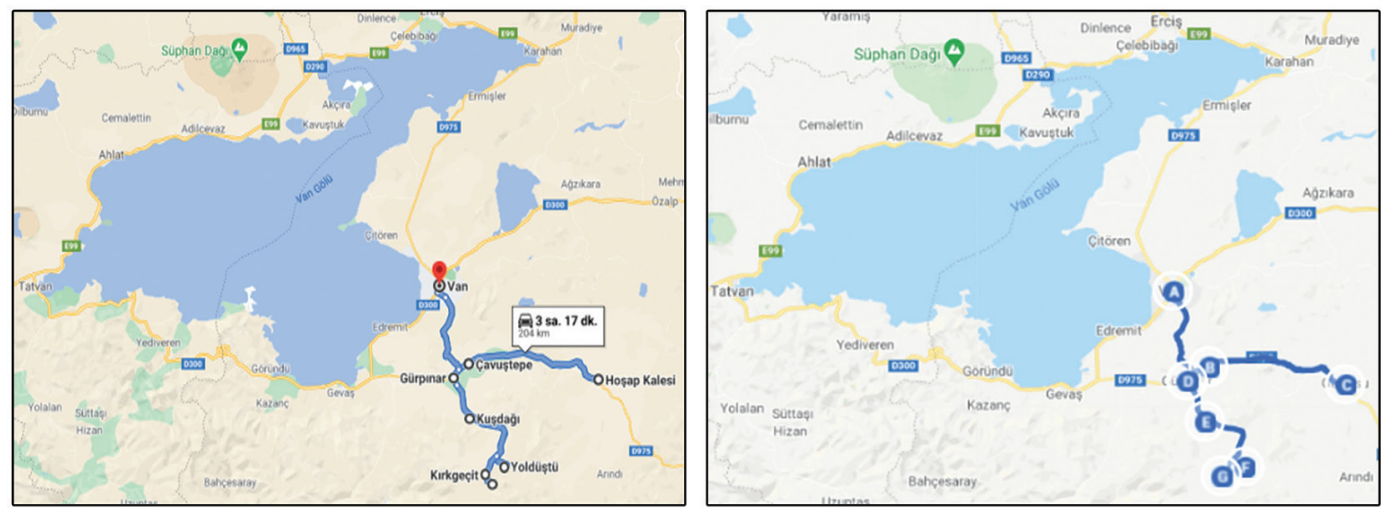

Şekil 3. Kültür rotası 2. harita üzerinde gösterimi

Figure 3. A map of cultural route 2

Tablo 3. Kültür rotası 2. planı

Table 3. The detailed plan 2 of cultural route

\begin{tabular}{|c|l|c|c|l|l|}
\hline Hareket Saati* & \multicolumn{1}{|c|}{ Hareket Noktası } & Mesafe $(\mathrm{km})$ & Varış Saati* & Valış Süresi (dk) \\
\hline 08.00 & Van (A) & 26,4 & 08.45 & Çavuştepe (B) & 90 \\
\hline 10.15 & Çavuştepe (B) & 36,1 & 10.45 & Hoşap (C) & 90 \\
\hline 12.15 & Hoşap (C) & 39,5 & 13.00 & Gürpınar/ Öğle Yemeği (D) \\
\hline 14.00 & Gürpınar (D) & $\sim 10,6-32,9$ & 14.30 & Norduz Yaylası/Peynir Çiftliği Ziyareti (E/F/G) & \multicolumn{1}{|c|}{90} \\
\hline 16.00 & Norduz Yaylası (E) & $\sim 60$ & 17.30 & Van (A) \\
\hline
\end{tabular}

* Google harita ve saha görüşmeleri ile verilen değerlerdir. hava, yol ve trafik yoğunluğu şartlarına bağlı değişebilir.
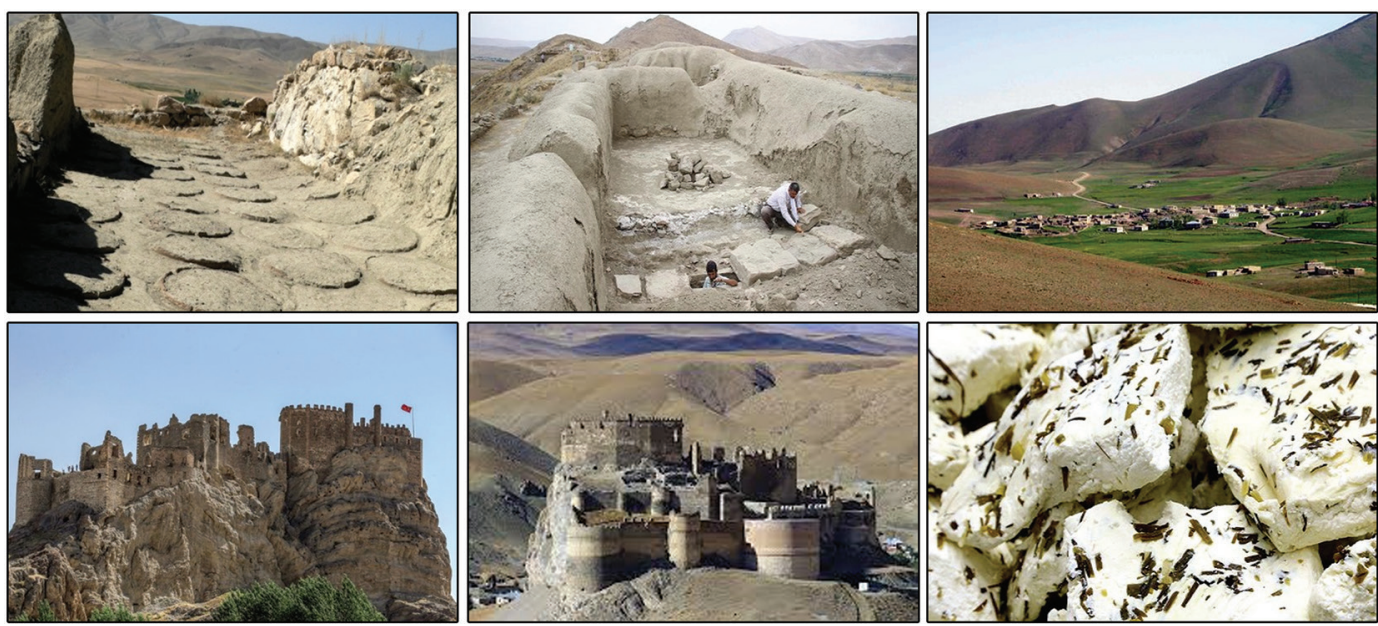

Fotoğraf 9. Kültür rotası 2.'de yer alan doğal ve kültürel değerlerden görünüm

Photo 9. A view of natural and cultural assets within cultural route 2 
Rota 3: Van - Akdamar Adası/Akdamar Kilisesi - Gevaş Van Otlu Peynir Çiftliği.

Bu rotada UNESCO Dünya Mirası Geçici listesinde yer alan Akdamar Anıt Müzesi (Surp Haç Kilisesi/Kutsal Haç Katedrali) ziyareti yer almaktadır. Akdamar iskelesinden (B noktası) tekne yolculuğu ile Van Gölü'nün muhteşem manzarası eşliğinde Akdamar Adasına ulaşılacaktır. Akdamar Anıt Müzesi (C) ziyareti sonrası Akdamar İskelesine (B) dönüş tekne ile yapılarak otobüsler ile Gevaş'ta planlanan peynir çiftliği (D) ziyareti yapılacaktır. Bu rotada öğlen yemeği ve peynir çiftliği ziyareti programda birleştirilmiş olarak yer almaktadır. Gevaş ilçesi veya Pınarbaşı, Dokuzağaç, Bağlama, Göründü köylerinden birinde yer alması planlanan peynir çiftliği ziyareti sonrasında Van merkeze (A) dönülecektir. Rota bir gün olarak planlanmıştır. Van merkeze dönüşte

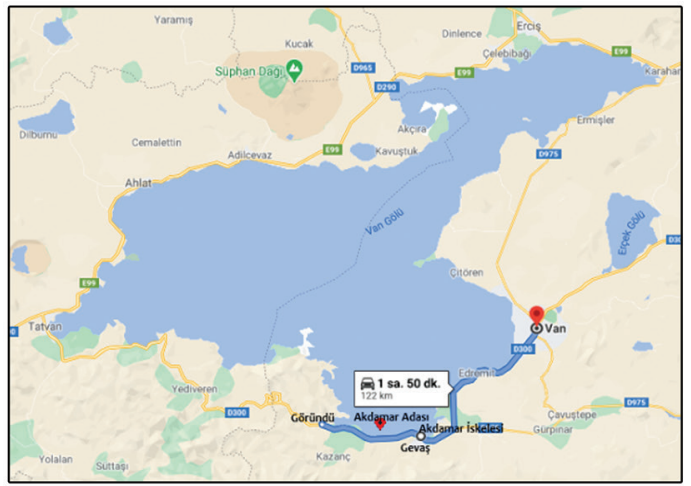

Şekil 4. Kültür rotası 3. harita üzerinde gösterimi

Figure 4. A map of cultural route 3

Tablo 4. Kültür rotası 3. planı

Table 4. The detailed plan 3 of cultural route

\begin{tabular}{|c|l|c|c|l|l|}
\hline Hareket Saati* & \multicolumn{1}{|c|}{ Hareket Noktası } & Mesafe $(\mathrm{km})$ & Varış Saati* & \multicolumn{1}{|c|}{ Kalış Süresi (dk) Noktası } \\
\hline 08.00 & Van (A) & 37,3 & 08.45 & Akdamar İskelesi/ Tekneye Aktarma (B) \\
\hline 09.00 & Akdamar İskelesi (B) & $\sim 8$ & 09.35 & $\begin{array}{l}\text { Akdamar Adası/ Akdamar Kilisesi (Surp Haç } \\
\text { Kilisesi) (C) }\end{array}$ \\
\hline 11.35 & Akdamar Adası (C) & $\sim 8$ & 12.10 & Akdamar İskelesi/ (B) Otobüse Aktarma \\
\hline 12.15 & Akdamar İskelesi (B) & 23,4 & 13.00 & $\begin{array}{l}\text { Gevaş Göründü Peynir Çiftliği Ziyareti ve Yöresel } \\
\text { Öğle Yemeği (D) }\end{array}$ \\
\hline 16.00 & $\begin{array}{l}\text { Gevaş Peynir Çiftliği Ziyareti ve } \\
\text { Yöresel Öğle Yemeği (D) }\end{array}$ & 60,8 & 17.15 & Van (A) \\
\hline
\end{tabular}

* Google harita ve saha görüşmeleri ille verilen değerlerdir. Hava, yol ve trafik yoğunluğu şartlarına bağlı değişebilir.
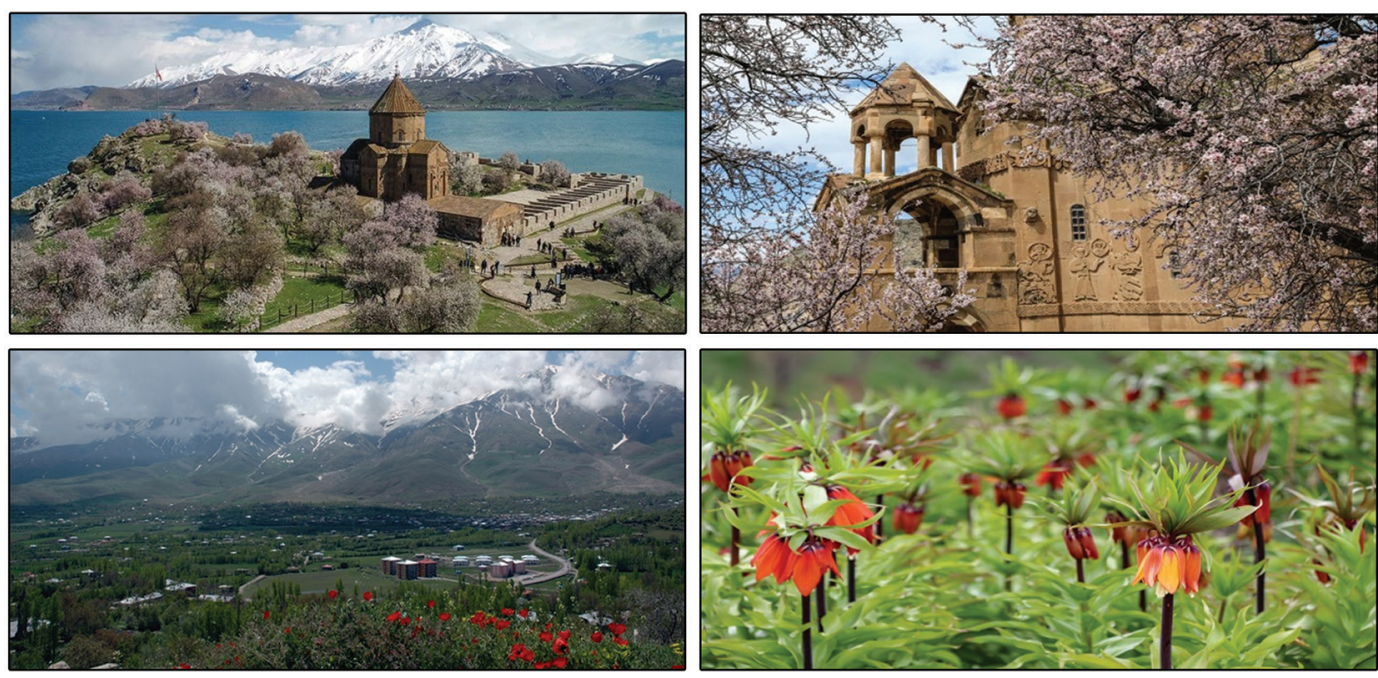

Fotoğraf 10. Kültür rotası 3.'de yer alan doğal ve kültürel değerlerden görünüm Photo 10. A view of natural and cultural assets within cultural route 3 
Rota 4: Van - Meher Kapı - Anzaf Kaleleri - Erçek Gölü - Özalp - Dönerdere Van Otlu Peynir Çiftliği

$\mathrm{Bu}$ rotada Van (A) merkezinden hareket sonrası ilk olarak Urartu dönemine ait Tanrı Haldi adına yaptırılan Meher Kapı (B) ve Aşağı Anzaf ve Yukarı Anzaf Kaleleri (C) görülecektir. Rotada bir sonraki durak biyoturizm ve ornitoturizm açısından dünyanın önemli merkezlerinden biri olan ve Çevre ve Şehircilik Bakanlığı tarafından Haziran 2020'de "Potansiyel Doğal Sit Alanı" ilan edilmiş Er-çek Gölü'dür (D). Erçek Gölü’ne göç yoluyla havaların ısınmasıyla gelen Flamingolar Ekim ayı sonuna kadar gözlenebilmektedir. Öğle yemeği molası önemli peynir üretim merkezlerinden biri olan Özalp ilçesinde verilecek ve bu rotanın son durağı olan Dönerdere köyü (E) ziyareti ve bu köyde planlanacak peynir çiftliğinde peynir üretimi deneyimlenebilecektir. 1965'te Trab-zon/ Çaykara Uzungöl Mahallesi'nde yaşanan heyelan dolayı-sıyla göç ederek Yukarı Dönerdere'ye yerleşen Karadenizli ai-leler hayvancılık ile uğraşmakta ve peynir yapımı konusunda oldukça başarılıdırlar. Bu rota diğer rotalarda olduğu gibi bir günlük olarak planlanmaktadır (89,8 km gidiş). Ziyaretçiler, dönüşte konaklama için merkezden km uzakta bulunan Özalp ilçesinde bulunan otellerde konaklayabilecekleri gibi tekrar Van'a konaklama içinde dönebilirler (Toplam 174 km). Buradaki köy aynı zamanda farklı bir kültürü yansıtan Karadeniz köyü olarak bilinmektedir. Bu nedenle, özellikle gezginler için farkIı bir kültür ve kültürel değerlerin deneyimlenmesi açısından önemlidir (Tablo 5) (Şekil 5) (Fotoğraf 11).
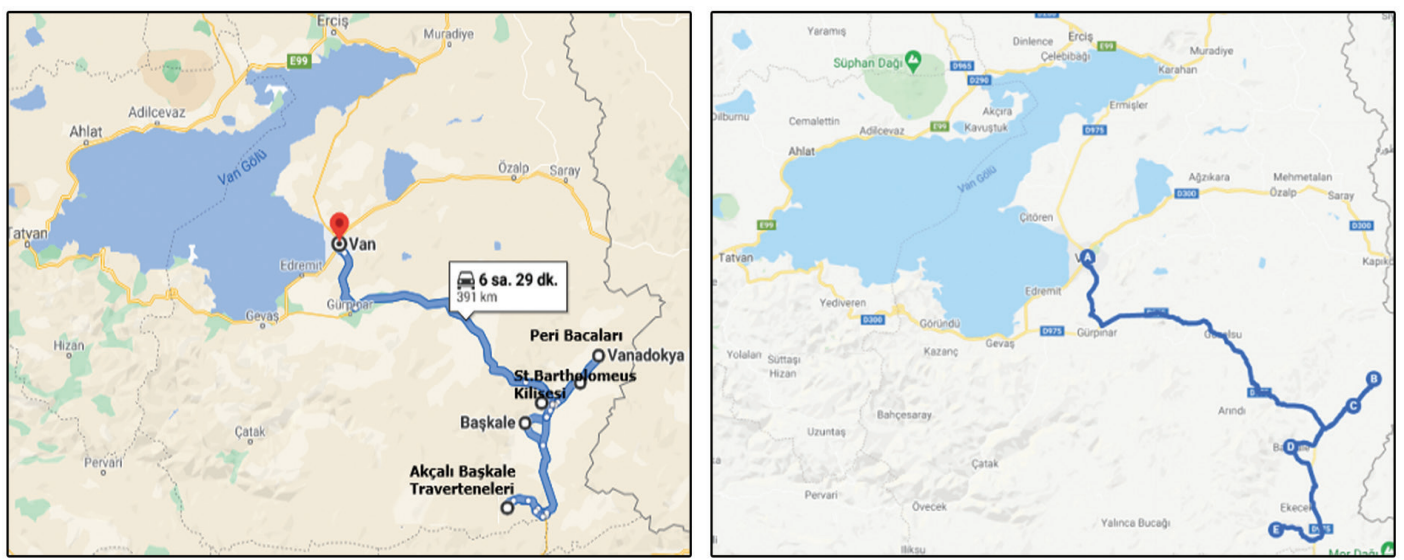

Şekil 5. Kültür rotası 4. harita üzerinde gösterimi

Figure 5. A map of cultural route 4

Tablo 5. Kültür rotası 4. planı

Table 5. The detailed plan 4 of cultural route

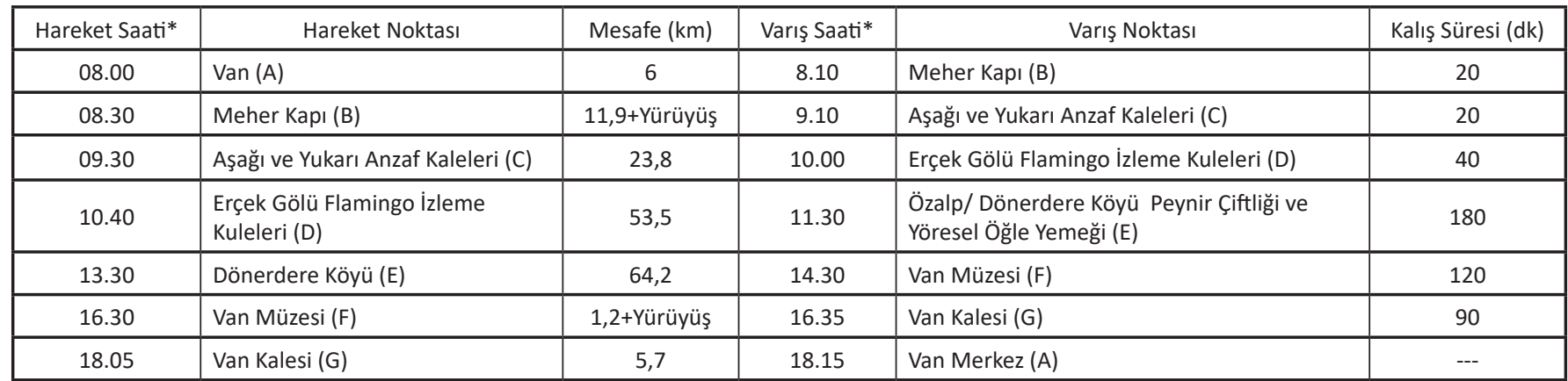

* Google harita ve saha görüşmeleri ile verilen değerlerdir. hava, yol ve trafik yoğunluğu şartlarına bağlı değişebilir.
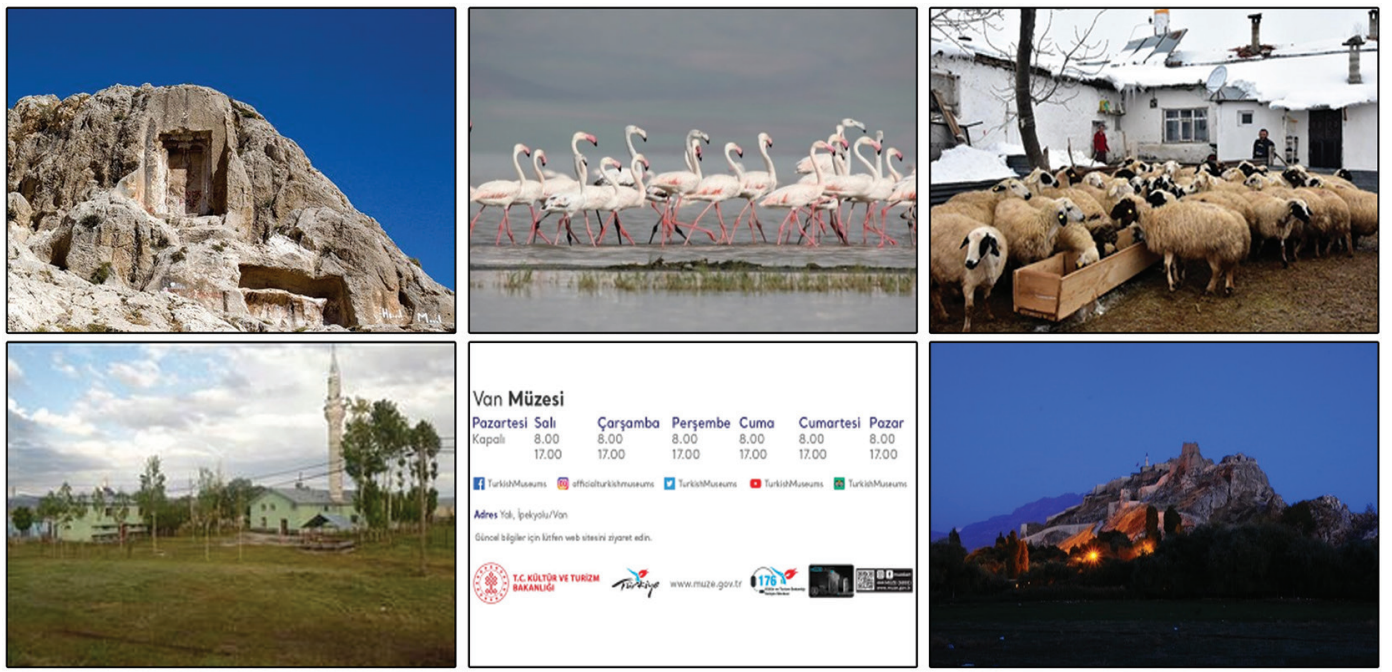

Fotoğraf 11. Kültür rotası 4.'de yer alan doğal ve kültürel değerlerden görünüm

Photo 11. A view of natural and cultural assets within cultural route 4 
Rota 5: Van - Van Kalesi - Yukarı Bakraçlı Köyü Yedi Kilise Peynir Çiftliği Ziyareti - Kalecik

Bu tur rotası Van'ın kent merkezi ve yakın çevresinde bulunan tarihi ve kültürel değerleri ile oluşturulmuştur. Rota, Urartu döneminden kalma Van Kalesi (B), Urartu dönemi Savat Gümüş işlemeciliği el sanatının tanıtılacağı gümüş atölyesi ziyareti ikinci durak olacaktır. Bu atölyede Van kedileri de görü-lebilecektir (C). Öğlen yemeği Yukarı Bakraçlı köyünde peynir çiftliği ziyareti ile birlikte planlanmıştır. Bu durakta 8. yüzyılda inşa edilmiş olan tarihî Ermeni manastırı Yedi Kilise

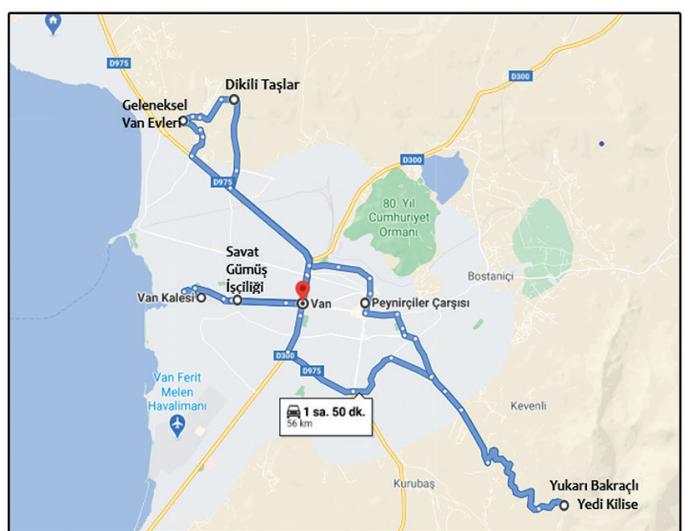

Şekil 6. Kültür rotası 5 . harita üzerinde gösterimi

Figure 6. A map of cultural route 5

Tablo 6. Kültür rotası 5. planı

Table 6. The detailed plan 5 of cultural route

\begin{tabular}{|c|l|c|c|l|l|}
\hline Hareket Saati* & \multicolumn{1}{|c|}{ Hareket Noktası } & Mesafe (km) & Varış Saati* & \multicolumn{1}{|c|}{ Kalış Süresi (dk) } \\
\hline 08.00 & Van (A) & 5,6 & 08.30 & Van Kalesi (B) \\
\hline 10.00 & Van Kalesi (B) & 4.9 & 10.15 & Savat Gümüş İşçiliği İzlemesi (C) \\
\hline 11.30 & Savat Gümüş İşiliği İzlemesi (C) & 16,6 & 12.15 & $\begin{array}{l}\text { Yukarı Bakraçlı Köyü Yedi Kilise } \\
\text { Peynir Çiftliği Ziyareti ve }\end{array}$ \\
\hline 14.15 & Yukaresel Öğle Yemeği (D)
\end{tabular}

* Google harita ve saha görüşmeleri ile verilen değerlerdir. hava, yol ve trafik yoğunluğu şartlarına bağlı değişebilir.
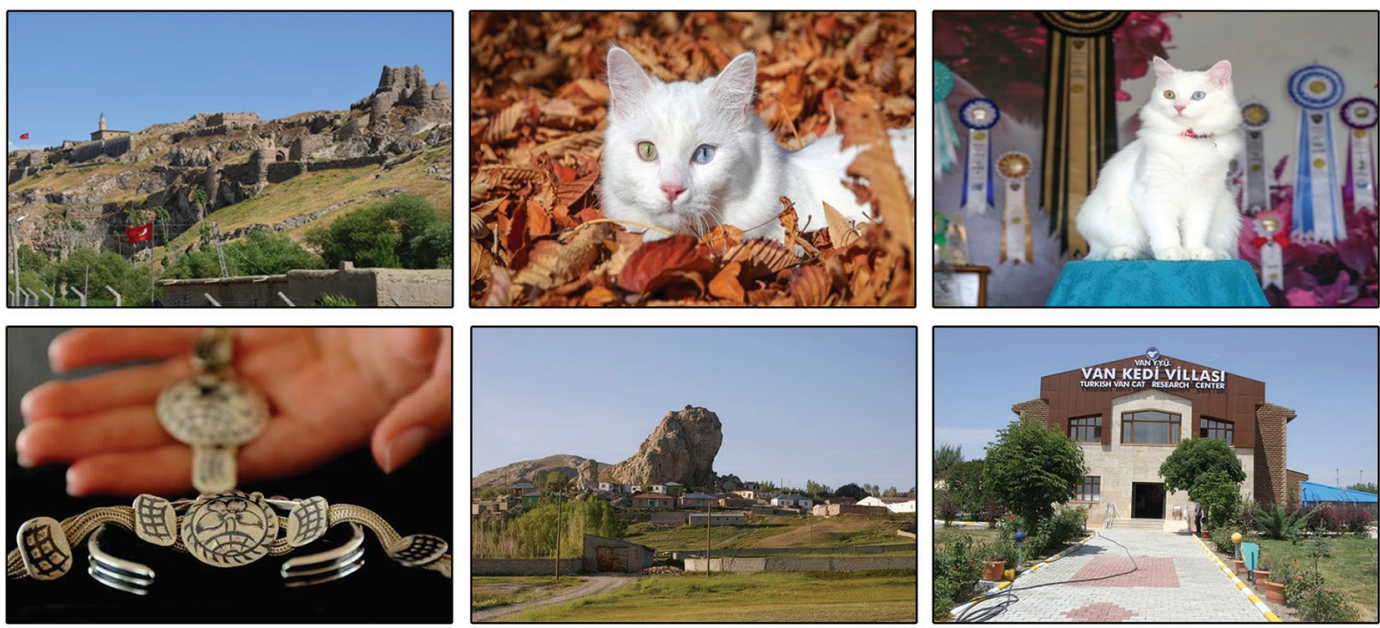

Fotoğraf 12. Kültür rotası 5.'de yer alan doğal ve kültürel değerlerden görünüm Photo 12. A view of natural and cultural assets within cultural route 5 


\section{1. Çok Günlük Rotalar}

Bu iki örnek rota tek bir peynir çiftliği ziyareti içermektedir. Burada yer verilmeyen Meher Kapı, Altınsaç Kilisesi (Sn.Thomas Kilisesi), Yukarı Bakraçlı Köyü Yedi Kilise, Urartu Su Kanalı Şamram (Menua Kanalı), Muradiye Şelalesi, Erciş Balık Göçü izlemesi, İnköyü Koyu, Vanadokya Yavuzlar Peri Bacaları, Çatak ilçesi-Hurkan Köprüsü gibi farklı noktalar farklı dönemlerde eklenebilir. (Fotoğraf 13)
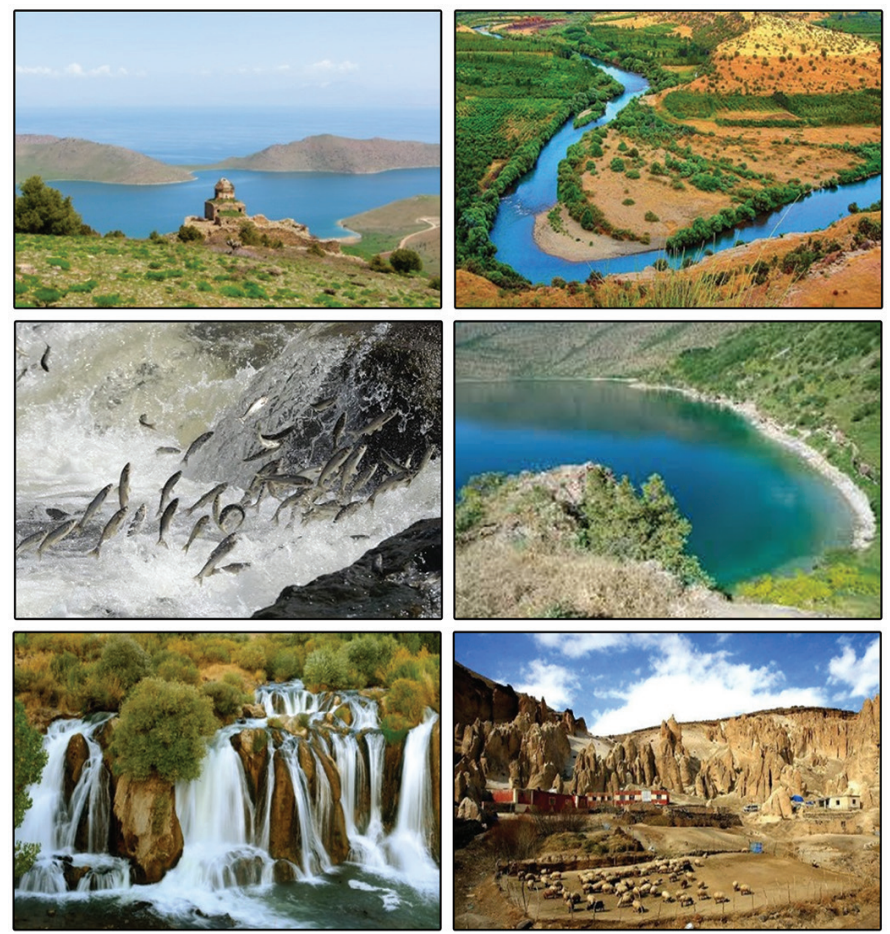

Fotoğraf 13. Çok günlük rotalarda yer alan doğal ve kültürel değerlerden görünüm

Photo 13. A view of natural and cultural assets within multiple-day routes

Rota 1: 3 gün 2 gece

1.Gün; Van merkez hareketli Akdamar Adası - Surp Haç Kilisesi - Van Gölü kıyısında öğlen yemeği - Van Müzesi -Savat işçiliği izlemesi - Van Kalesi (güneş batışı izlenmesi) - Van merkeze dönüş. 2.Gün; Van merkez hareketli Çavuştepe Kalesi - Hoşap Kalesi - öğlen yemeği - Norduz Yaylası peynirçiftliği ziyareti - Van merkeze dönüş. 3. Gün; Erçek Gölü - Flamingo Gözlemi -Özalp'ta öğlen yemeği - Van YYU Van Kedi Villası - Kalecik Dikili Taşlar-Geleneksel Van Evleri Van merkeze dönüş.

\section{Rota 2: 4 gün 3 gece}

1.Gün; Van merkez hareketli Akdamar Adası - Surp Haç Kilisesi - Van Gölü kıyısında öğlen yemeği - Gevaş ilçe turu peynir çiftliği ziyareti - Van merkeze dönüş. 2.Gün; Van merkez hareketli Van Kalesi - Savat işçiliği izlemesi - öğlen yemeği - Van Müzesi - Van Evleri - Van YYU Kedi Villası - Van merkeze dönüş. 3.Gün; Van merkez hareketli Çavuştepe Kalesi - Hoşap Kalesi - öğlen yemeği - Başkale Travertenleri Van merkeze dönüş. 4. Gün; Erçek Gölü - Flamingo gözlemi öğlen yemeği - Dönerdere köyü ziyareti - Van YYU Van Kedi Villası - Van merkeze dönüş.

\section{Sonuç}

Bu araştırma kapsamında hem sahada yapılan gözlemler hem de sektör temsilcileriyle yapılan görüşmeler sonucunda Van otlu peynirinin turistik ürün olarak ziyaretçilere sunulabilmesi için oluşturulabilecek tematik/kültür turizm rotalarına yönelik bir değerlendirme yapılmıştır.

Araştırma sonucunda özellikle Van otlu peyniri üretim mekanlarının hayvancılığın yoğun olarak sürdürüldüğü Gürpınar, Başkale, Çatak, Özalp, Gevaş ilçelerinde ve Norduz Yaylasında yoğunlaştığı görülmektedir. Ancak, yurt dışı ve Türkiye'de iyi örnekler göz önüne alındığında bölgede yoğun bir şekilde peynir üretimi yapılmasına ve pazarlanmasına rağmen peynir turizmine ilişkin bir çalışmanın bugüne kadar yapılmadığı görülmektedir. Ulusal ve uluslararası boyutta peynir ele alındığında Van otlu peynirinin, bugün sadece Van Kahvaltısı içinde sunulan bir bileşen olduğu ya da Tarihi Peynirciler Çarşısı veya yerel marketlerde satışı yapılarak ziyaretçilerle buluşturulan bir ürün olduğu görülmektedir. Bu çerçevede, Van otlu peynirinin uluslararası iyi örneklerde olduğu gibi turistik ürün olması çalışmalarında geç kalındığı ancak somut olmayan kültürel bir değer olarak turistik ürün olma potansiyelinin yüksek olduğu ifade edilebilir.

Bölgede var olduğu düşünülen peynir turizmi potansiyelinin tam anlamıyla kullanılabilmesi için iyi uygulamalar incelendiğinde peynir festivalleri, peynir müzeleri, peynir tadım turları ve peynir üretim deneyimlemesine uygun bütünleşik peynir atölyelerini içeren çiftlikler ve peynir çiftliklerinin içinde yer aldığı kültür rotalarının oluşturulması gerektiği ve ayrıca tanıtım pazarlama faaliyetlerinin bütünleşik bir şekilde yürütüleceği destinasyon yönetimi eksikliği ortaya çıkmıştır.

$\mathrm{Bu}$ anlamda bu potansiyelin kullanılmasında farkındalık yaratmak yerel üreticilerde-yerel paydaşlara ve yatırımcılarda farkındalık yaratmak için bu çalışma ile Van Otlu peynir yapım sürecinin deneyimlenebileceği hikayesinin turistik bir ürün olarak ziyaretçiler ile paylaşılabileceği mekanlar tespit edilerek potansiyel turizm rotalarının oluşturulmasına çalışımıştır. Bu süreçte özellikle sektör paydaşları süreç içerisine dahil edilerek katılımc bir yaklaşım ile gerçekçi ve sektörün gelecekte uygulamaya dönüştürebileceği rota planları ortaya konulmaya çalışılmıştır.

Bu araştırmada ayrıca oluşturulan kültür rotaları ile peynir turizminin diğer turistik ürün ve hizmetler ile nasıl bir araya getirilebileceği ve peynirin turistik bir ürün olarak pazarlanması sürecinde kentin kültürel ve doğal mirasının turizm faaliyetleri içinde sürdürülebilirliğine önemli katkı sağlayacağı düşünülmektedir. Bugün yeterince korunamayan somut ve soyut kültürel mirasın da oluşturulan kültür rotalarının sürdürülebilmesi için hem yerel halk hem de yerel yönetimlerce korunmaya ve yeniden aslına uygun restorasyonlarının yapılmasına katkı sağlayacağı düşünülmektedir. 
Ancak, peynirin turizm süreçlerine entegre edilebilmesi görülmüştür. Bunların başında hijyen, sağlık, standartlaşma gibi temel hususlar gelmektedir. Üretilen ürünlerin turizm sürecine dahil edilmesi noktasında ise girişimcilik, pazarlama ve hizmet kalitesi gibi diğer önemli hususlar öne çıkmaktadır. Bunların oluşturulabilmesi noktasında yerel girişimlerin özellikle turizm sektörüyle bir araya gelmesi ve bu çerçevede de özellikle kadın girişimcilerin desteklenmesi gerekmektedir. $\mathrm{Bu}$ çerçevede bakıldığında kadın emeğinin kırsaldaki üretim sürecinde çok yoğun olmasına rağmen, ekonomik karşılığının yeterince ya da hiç olmadığı görülmektedir (Cihangir vd. 2020). Bu çerçevede, peynir üretim süreçlerinin ev içi tüketim ya da tüketim fazlası ürünün tüccarlara pazarlanması yerine peynir turizmi ile yerel üreticiye ve özellikle emek-yoğun çalışan kırsal kadına yerel girişimci olabilme fırsatı sunulacaktır. Kırsaldaki kadın girişimci sayısının artırılması ve bunlara yönelik hibe desteklerinin sağlanması da bu süreçte atılması gereken en önemli adımlardan biri olarak görülmektedir. Bu anlamda yapılan benzer araştırmalarda kadın girişimcilere verilen desteklerin, pozitif ayrımcılık politikalarının önemli olduğunu göstermektedir. Yerel girişimcilerin artması gelirlerin yerele yayılmasında, toplumdaki kırılgan grupların istihdama katılmasında ve toplumsal cinsiyet ilişkilerinde muhafazakâr yapılardaki eşitsizliklerin giderilmesinde önemli gelişmelerin ortaya çıkmasını, kadınların sosyo-ekonomik hayatta görünür olmalarını sağlamada önemli etkiler yaratacağı düşünülmektedir (Çamur Cihangir \& Cihangir, 2017: 236).

Bu çalışmanın diğer önemli bir çıktısı Van otlu peynirinin hem lezzet olarak hem de üretim sürecine ilişkin hikâyesi ile yurt dışında ve yurt içinde turistik ürün olarak pazarlanan peynirlerden bir farkı olmadığıdır. Bu çerçevede, ulusal ve özellikle uluslararası düzeyde peynir turizmine ilişkin iyi uygulamalar incelenerek, Van otlu peynirinin üretim sürecine ilişkin hikâyesinin deneyimlenebileceği çiftliklerin/mekanların Van kültür rotalarında yer alması hatta sadece peynir üretimine özel turlar oluşturularak ziyaretçilerin bu keyifli süreci çiftliklerde ya da yaylalarda yerel üreticiler ile birlikte deneyimlemeleri sağlanmalıdır. Turizm yatırımcılarının, yerel halk ve yerel otoriteler ile birlikte bu yönde hızla adım atması önemli görülmektedir. Bu çerçevede bu araştırmada önerilen rotaların önemli bir baz oluşturacağı düşünülmektedir.

Sonuç olarak, Van otlu peynirinin hak ettiği şekilde bir turistik ürün olması ile hem kente sağladığı ekonomik katma değeri artacak hem de üretim sürecinde yoğun emeği olan kırsalda yaşayan "kırsal kadının" güçlendirilmesine katkı sağlanmış olacaktır. Ekonomik anlamda kente sağlayacağı yarar anlamında bakıldığında, örneğin; Kars gravyer peynirinin, Arınç (2018: 16) tarafından belirtilen tahmini yıllık gelir miktarının 2 ile 2,5 milyon TL'lik bir iktisadi faaliyet oluşturduğu düşünülürse, 600 binden fazla küçükbaş hayvan nedenle peynirin sadece bir yerel yiyecek olarak pazarlanması sayısına sahip olan Van için Van otlu peynirinin çok önemli bir gelir yaratacağı söylenebilir. Van otlu peynirinin sürdürülebilir bir turistik ürün olması geleneksel üretiminin gelecek nesillere aktarılmasını, hayvancılığın bölgede gelişmesini ve istihdam sorunlarının giderilmesini de destekleyecektir. Bu nedenle peynirin sadece bir yerel yiyecek olarak pazarlanması yerine somut olmayan kültürel miras olarak değerlendirilerek hikâyesi ile birlikte turistik bir ürün olarak ele alınıp stratejilerin buna göre oluşturulması sağlanmalıdır.

\section{Kaynakça}

Akdu, U. \& Akdu, S. (2018). Turizm tanıtımında gastronomik değer vurgusu: UNESCO Gastronomi Şehirleri. Journal of Tourism and Gastronomy Studies, 6(4), 933-952.

Akgöz, E. Göral, R. \& Tengilimoğlu, E. (2016). Turistik ürün çeşitlendirmenin sürdürülebilir destinasyonlar açısından önemi. Akademik Bakış Dergisi, 55, 397-407.

Aksoy, M. \& Sezgi, G. (2015). Gastronomi turizmi ve Güneydoğu Anadolu Bölgesi gastronomik unsurları. Journal of Tourism and Gastronomy Studies, 3(3), 79-89.

Akyüz, N. \& Coşkun, H. (1996). Van otlu peynirlerinin üretimi ve peynire katılan otların peynirin çeşitli özellikleri üzerine etkileri. M. Demirci (Ed.), Her yönüyle peynir içinde (ss.210-216). İstanbul: Hasad Yayıncılık Ltd. Şti.

Akyüz, N., Coşkun, H., Andiç, S. \& Altun, İ. (1996). Some general characteristics of pickled herbs used in making Van herby cheese. Yüzüncü Yıl Üniversitesi Tarım Bilimleri Dergisi, 6(1), 35-41.

Arınç, K. (2018). Boğatepe köyünde Gravyer peyniri üretimi ve sürdürülebilir gelişme bakımından önemi (Kars/Türkiye). Türk Coğrafya Dergisi, 70, 7-18.

Atı̧ E. \& Çelikoğlu. Ş. (2017). Boğatepe köyünde geleneksel Kars gravyer ve kaşar peyniri üretiminin yöre ekonomisi ve tanıtımına katkısı, November 2017 International Congress on the 75th Anniversary of TGS - TCK 75. Kuruluş Yılı Uluslararası Kongresi, 310-324.

Babbie E. (2016). The Practice of Social Research. Fourteenth Edition, Boston: Cengage Learning.

Başaran, B. (2017). Gastronomi turizmi kapsamında Rize yöresel lezzetlerinin değerlendirilmesi. Journal of Tourism and Gastronomy Studies, 5(3), 135-149.

Biber H. \& Çavuşoğlu R. (2005). Van/Kalecik Urartu Gözlem Alanı ve Nekropolü. Arkeoloji ve Sanat, (27/120), 17-28.

Bogue, J. C., Delahunty, C. M., Henry, M. K. \& Murray, J. M. (1999). Market-oriented methodologies to optimise consumer acceptability of Cheddar-type cheeses. British Food Journal, 101(4), 301-317.

Cihangir Çamur, K. \& Cihangir, E. (2017). Turizm temelli girişimciliğin gelişiminde yerel ve mekânsal dinamiklerin Göreme (Nevşehir-Kapadokya) örneğinde analizi. Van Yüzüncü Yıl Üniversitesi Sosyal Bilimler Enstitüsü Dergisi, 1(3), 227-237.

Cihangir, E. \& Şeremet, M. (2020). Van'ın Edremit ilçesinde turizmin gelişimi: Rezilyans ve değişim. Türk Coğrafya Dergisi (74), 47-59.

Cihangir, E., Demirhan, Ö. \& Şeremet, M. (2020). Kırsal turizm potansiyelinin ortaya çıkarılmasında kırsalda kadının durumuna bir bakış: Van otlu peyniri üretimi örneği. International Journal of Geography and Geography Education, (42), 199-222.

Corbin, J. \& Strauss, A. (2015). Basics of qualitative research: Techniques and procedures for developing grounded theory. Fourth Edition. Sage Publications.

Coşkun, H. \& Öztürk, B. (2001). Otlu peynir adı alttnda üretilen peynirler üzerinde bir araştırma. Gıda Mühendisliği Dergisi, 10, 19-23.

Cömert, M. (2014). Turizm pazarlamasında yöresel mutfakların önemi ve Hatay mutfağı örneği. Journal of Tourism and Gastronomy Studies, 2(1), 64-70. 
Cömert, M. \& Sökmen, A. (2017). Türkiye'de gastronomi turizmi: Antalya'da konaklayan turistler üzerine bir araşttrma. Seyahat ve Otel İşetmeciliği Dergisi, 14(3),6-26.

Creswell, J. W. (2014). Research design: Qualitative, quantitative, and mixed methods approaches. London: Sage Publications.

Cunningham J.M., Shukla G. \& Tikkanen A. (2007). Roquefort Cheese. Encyclopædia Britannica. https://www.britannica.com/topic/ Roquefort\#accordion-article-history

Çakır, A., Çiftçi, G. \& Çakır, G. (2017). Trakya turizm rotası projesi: Lezzet rotası üzerine bir değerlendirme. Journal of Tourism and Gastronomy Studies, 5(2), 194-205.

Çatır, O. \& Ay, E. (2018). Ulubey (Uşak) yöresel yemeklerinin gastronomi turizmi açısından değerlendirilmesi. Journal of Tourism and Gastronomy Studies, 6(3), 3-19.

Çavuşoğlu R., Biber H. \& Başar F. (2008). 2004-2007 Yılları Van-Kalecik Kazıları. H. Dönmez \& A. Özme (Ed.), 30. Kazı Sonuçları Toplantısı içinde (ss.269-289). Kültür ve Turizm Bakanlığı, Kültür Varlıkları ve Müzeler Genel Müdürlüğü.1. Cilt, Ankara.

ÇEKÜL Vakfi. (2014). Gaziantep kültürel rotalar sistemi. Mekansal planlama rehberi kültür öncelikli bölgesel yol haritaları. Erişim Adresi https://drive.google.com/file/d/OBxSivl_OYdzVeTZwUE9pdjlLSG8/view

ÇEKÜL Vakfi. (2015). Kültür rotaları planlama rehberi. Tarihi kentler birliği yayınları kılavuz kitapçıklar dizisi 3. İstanbul. Erişim adresi https://www.tarihikentlerbirligi.org/wp-content/uploads/rota-rehberi_press.pdf

Çimen, H. (2016). Gastronomi turizmi açısından Ardahan mutfağının önemi. Karadeniz-Blacksea-Черное море, (32), 307-315.

Çolakoğlu, O. (2014). Turistik Ürün Politikası. 1.Baskı. Ankara: Detay Yayıncılık.

DAKA (2019). Van-Bitlis turizm odaklı tanıtım ve markalaşma eylem planı. Erişim adresi https://www.daka.org.tr/panel/files/files/ yayinlar/ VAN\%20B\%C4\%BOTL\%C4\% BOS\%20TUR\%C4\%BOZ\%C4\%BOM\%20\%20ODAKLI\%20TANITIM\%20VE\%20MARKALA\%C5\%9EMA\%20EYLEM\%2OPLANI.pdf

Denzin, N. K. (1978). The research act: A theoretical introduction to sociological methods. (2nd ed.). New York: McGraw-Hill.

Denzin, N. K. \& Lincoln, Y. S. (2018). The Sage handbook of qualitative research. Fifth Edition. London: Sage Publications.

Deveci, B., Türkmen, S. \& Avcıkurt, C. (2013). Kırsal turizm ile gastronomi turizmi ilişkisi: Bigadiç örneği. Uluslararası Sosyal ve Ekonomik Bilimler Dergisi, 3(2), 29-34.

Durlu Özkaya, F., Sünnetçioğlu, S. \& Can, A. (2013). Sürdürülebilir gastronomi turizmi hareketliliğinde coğrafi işaretlemenin rolü. Journal of Tourism and Gastronomy Studies, 1(1), 13-20.

Eisenhardt, K. M. (1989). Building theories from case study research. Academy of management review, 14(4), 532-550.

Everett, S. (2008). Beyond the visual gaze? The pursuit of an embodied experience through food tourism. Tourist Studies, 8(3), 337-358.

Flyvbjerg, B. (2011). Case study. In N.K. Denzin \& Y.S. Lincoln (Eds.), The Sage Handbook of Qualitative Research (pp. 301-316). 4th Edition, Thousand Oaks, CA: Sage,

Flick, U. (2018). Triangulation in data collection. In U. Flick (Ed.), The SAGE handbook of qualitative data collection (pp.527-544). London: Sage Publications.

Fusté Forné, F. (2015a). Cheese tourism in a world heritage site: Vall de Boí (Catalan Pyrenees). European Journal of Tourism Research, 11, 87-101.
Fusté Forné, F. (2015b). Local cheese in farmers' markets: Community and tourism development in Canterbury, New Zealand. e-Review of Tourism Research(eRTR), 2015, 12 (5/6), 281-289.

Golafshani, N. (2003). Understanding reliability and validity in qualitative research. The qualitative report, 8(4), 597-607.

Gökdeniz, A., Erdem, B., Dinç, Y. \& Uğuz, S. Ç. (2015). Gastronomi turizmi: Ayvalık'ta yerli turistler üzerinde görgül bir araştırma. Journal of Tourism and Gastronomy Studies, 3(1), 14-29.

Görmüş S. (2017). Kültürel peyzaj değerlerini korumak için yeni bir yaklaşım: Kültürel rotalar. Plant Peyzaj ve Süs Bitkiciliği Dergisi, 7(25), 122-130.

Gürbüz, S. \& Şahin, F. (2014). Sosyal bilimlerde araştırma yöntemleri. Ankara: Seçkin Yayıncılık.

Gürsoy, Y. (2017). Giresun merkez yöresinde gastronomi turizmi üzerine genel bir değerlendirme. Journal of International Social Research, 10 (51), 1296-1304.

Hacıoğlu, N. (2000). Turizm Pazarlaması. Bursa: Vipaş A.Ş.

Hacıoğlu, N. \& Avcıkurt (2011). Turizm Ürün Çeşitlendirmesi. Ankara: Nobel Akademik Yayıncılık.

Harbutt, J. (2009). World cheese book. London: Penguin.

Hatipoğlu, A., Zengin, B., Batman, O. \& Şengül, S. (2013). Yöresel yemeklerin, kırsal turizm işletmeleri mönülerinde kullanım düzeyleri: Gelveri örneği. International Journal of Social and Economic Sciences, 3(1), 6-11.

İşleyici, Ö. \& Sancak, Y. (2005). Van otlu peyniri, Yüzüncü Yıl Üniversitesi Sağlık Bilimleri Dergisi, 8 (1-2), 48-58.

İşleyici, Ö. \& Akyüz, N. (2009). Van ilinde satışa sunulan otlu peynirlerde mikrofloranın ve laktik asit bakterilerinin belirlenmesi. Yüzüncü Yıl Üniversitesi Veteriner Fakültesi Dergisi, 20(2), 59-64.

Jarábková, J. \& Hamada, M. (2012). Creativity and rural tourism. Creative and Knowledge Society, 2(2), 5-15.

Jupp, V. (2006). The Sage dictionary of social research methods. Sage Publications.

Kahraman, T., Ozmen, G.,Ozinan, B. \& Omer Goksoy, E. (2010). Prevalence of salmonella spp. and listeria monocytogenes in different cheese types produced in Turkey. British Food Journal, $112(11), 1230-1236$.

Kan, M., Gülçubuk, B., Kan, A. \& Küçükçongar, M. (2010). Coğrafi işaret olarak Karaman Divle Tulum Peyniri. Karamanoğlu Mehmetbey Üniversitesi Sosyal ve Ekonomik Araştirmalar Dergisi, (2), 15-23.

Karaca, O. B. (2016). Geleneksel peynirlerimizin gastronomi turizmindeki önemi. Journal of Tourism and Gastronomy Studies $4(2), 17-39$.

Kervankıran, i. \& Çuhadar, M. (2014). Turizm rotalarının oluşturulmasında Coğrafi Bilgi Sistemlerinin önemi. III. Disiplinlerarası Turizm Araştırmaları Kongresi, 04-05 Nisan 2014, Kuşadası, Aydın, (576-589).

Kesici, M. (2012). Kırsal turizme olan talepte yöresel yiyecek ve içecek kültürünün rolü. Kırklareli Üniversitesi, Sosyal ve Ekonomik Araştırmalar Dergisi, 14 (23), 33-37.

Kızılırmak, I.,, Albayrak, A. \& Küçükali, S. (2014). Yöresel mutfağın kırsal turizm işletmelerinde uygulanması: Uzungöl örneği. International Journal of Social and Economic Sciences, 4(1), 75-83.

Kurt, A. \& Akyüz, N. (1984). Van otlu peynirinin yapılışı ve mikrobiyolojik, fiziksel ve kimyasal nitelikleri. Gıda, 9(3), 141-146.

Layton, T. A. (1973). The cheese handbook: Over 250 varieties described, with Recipes. Courier Dover Publications. 
LeCompte, M. D. \& Goetz, J. P. (1982). Problems of reliability and validity in ethnographic research. Review of Educational Research, 52(1), 31-60.

Lourens, M. (2007). Route tourism: a roadmap for successful destinations and local economic development. Development Southern Africa, 24(3), 475-490.

Lune, H. \& Berg, B. L. (2017). Qualitative research methods for the social sciences. Ninth Edition, Global Edition. England: Pearson Education Limited.

Maurer, Oswin. (2018). Tourism and Food: Necessity or Experience? In S. Beeton \& A. Morrison (Eds.), The Study of Food, Tourism, Hospitality and Events: 21st-Century Approaches (pp.27-36). Singapore: Springer.

McCarthy, M., O’Reilly, S. \& Cronin, M. (2001). Psychological, attitudinal and behavioural characteristics of Irish speciality cheese customers. British Food Journal, 103(5), 313-330.

Mercan, Ş.O. \& Üzülmez, M. (2014). Coğrafi işaretlerin bölgesel turizm gelişimindeki önemi: Çanakkale ili örneği. Dokuz Eylül Üniversitesi İktisadi Idari Bilimler Fakültesi Dergisi, 29(2), 67-94.

Merriam, S. B. \& Tisdell, E. J. (2016). Qualitative research: A guide to design and implementation. 4th Edition. John Wiley \& Sons. USA.

Meyer, D. (2004). Tourism Routes and Gateways. Key issues for the development of tourism routes and gateways and their potential for Pro-Poor Tourism. Overseas Development Institute. https:// www.odi.org/sites/odi.org.uk/files/odi-assets/publications-opinion-files/4040.pdf

Meyer, D., Ashley, C. \& Poultney, C. (2004). Developing local excursions for tourists. Case Study (Brief No. 5). Pro-poor Tourism Pilots (Southern Africa) Programme. Erişim Tarihi: 20 Kasım 2019. https://www.odi.org/sites/odi.org.uk/files/odi-assets/publications-opinion-files/3794.pdf

Ocak, E. \& Köse, S. (2015). Van otlu peynirinin üretimi ve mineral madde içeriği. Gıda, 40(6), 343-348.

Okumuş, E. (2008). Evliya Çelebi'nin Seyahatnâme'sinde Tatvan ve Çevresi. Selçuk Üniversitesi Türkiyat Araştırmaları Dergisi, (24), 187-216.

Oliaei, Y. S. B. (2016). Jajikhli Panir. In C. Donnelly (Ed.), The Oxford companion to cheese (pp.390). Oxford University Press, New York, United States of America.

Öney Tan, A. (2016). Turkey. In C. Donnelly (Ed.), The Oxford companion to cheese (pp.732-734). Oxford University Press, New York United States of America.

Özkan, Ç. \& Aydın, Ş. (2018). Yerel yiyecekler aracılığı ile sürdürülebilir destinasyonlar: Ayvacık örneği, Journal of Tourism and Gastronomy Studies, 6(1), 335-349.

Özleyen, E. \& Tepeci, M. (2017). Manisa'da yöresel yemeklerin ve lezzetlerin turizmin gelişimine katkısının belirlenmesi. Turizm Akademik Dergisi, 4(2), 139-152.

Patton, M. Q. (2015). Qualitative research \& evaluation methods: Integrating theory and practice. Fourth edition. Sage publications.

Polat, E. (2017). Turizm ve coğrafi işaretleme: Balıkesir örneği. Meriç Uluslararası Sosyal ve Stratejik Araştırmalar Dergisi, 1(1), 17-31.

Ren, C. (2010). Assembling the socio-material destination: An actor-network approach to cultural tourism studies. In G. Richards, \& W. Munsters (Eds.), Cultural Tourism Research Methods (pp. 199-208). Oxfordshire, UK \& Cambridge, USA.

Ren, C. (2011). Non-human agency, radical ontology and tourism realities. Annals of Tourism Research, 38(3), 858-881.

Rogerson, C. M. (2009). Local economic development and tourism planning in Africa: evidence from route tourism in South Africa. In P. Hottola (Ed.), Tourism strategies and local responses in Southern Africa (pp.27-40). Wallingford: CAB
Sahin, G. G. (2015). Gastronomy tourism as an alternative tourism: an assessment on the gastronomy tourism potential of Turkey. International Journal of Academic Research in Business Social Science, 5(9), 79-105.

Schmudde, U. \& Sörensson, A. (2020). Tourism Development in Rural Areas in Sweden - In the Shadow of a Well-Established Destination. Athens Journal of Tourism, 7(1), 55-74.

Şahin, G. G. \& Ünver, G. (2015). Destinasyon pazarlama aracı olarak gastronomi turizmi: İstanbul'un gastronomi turizmi potansiyeli üzerine bir araşttrma. Journal of Tourism and Gastronomy Studies, 3(2), 63-73.

Şahin, K., Andiç, S. \& Koç, S. (2001). Van ili kentsel alanda ailelerin otlu peynir ve süt ürünleri alım ve tüketim davranışları. Yüzüncü Yıl Üniversitesi Tarım Bilimleri Dergisi, 11(2), 67-73.

Şehribanoğlu, S., Cihangir, E., Levendoğlu, M. F., \& Saydan, R. (2017). Kent, kimlik ve imaj: Van ili örneği. Van Yüzüncü Yıl Üniversitesi Sosyal Bilimler Enstitüsü Dergisi, KAYFOR Özel Sayı 4, 566-574.

Şeremet, M. \& Alaeddinoğlu, F. (2016). Turizm coğrafyası çalışmalarında örnek olay araştırması. N. Özgen (Ed.), Beşeri coğrafyada araştrrma yöntemleri ve teknikler içinde (ss.355-370). Ankara: Paradigma Akademi.

Silva, T., Santos, P., Silva, T., Silva, K., Machado, A. \& Garcia, L. (2019). Shelf life study of handmade and industrially processed Minas frescal cheese. Nutrition \& Food Science, (49/6), 1207-1218

Stake, R. E. (2006). Multiple case study analysis. New York: Guilford Press.

Stanley, J. \& Stanley, L. (2014). Food tourism: A practical marketing guide, Croydon: Cabi.

Stoddart, H. I. (2008). Route tourism and local economic development in South Africa: The Magalies meander and the crocodile ramble (Doctoral dissertation, University of the Witwatersrand).

Stone, M.J., Migacz, S., Garibaldi, R., Stein, N., \& Wolf, E. (2020). 2020 State of the Food Travel Industry Report Portland, OR: World Food Travel Association (WFTA)

Tarakçı, Z. \& Küçüköner, E. (2006). Farklı yağ oranına sahip sütten üretilen Van otlu peynirlerinde olgunlaşma süresinde meydana gelen değişiklikler. Yüzüncü Yıl Üniversitesi Tarım Bilimleri Dergisi, 16(1), 19-24.

Tekelioğlu, Y. (2011). Roquefort: Bir peynir, bir köy I. Gastro, Sayı 62, Temmuz, Ağustos, Eylül, Apa Unipirint Basım A.Ş. İstanbul, 70-76. https://catalogues.metro-group.com/metro-gastro/sayi-62-temmuz-agustos-eylul-2011/page/6-7

Top, M. (2017). Hoşap Kalesi Kazısı 2015 yılı kazı ve restorasyon çaIışması. XX. International Symposium of The Medieval Turkish Period Excavations History of Art Researches. Conference Proceedings. Erişim adresi http://Www.Xxortacag.Sakarya.Edu.Tr/ Pdf/39mtop.Pdf

Tunçtürk, Y., Ocak E. \& Köse, Ş. (2014). Farklı süt türlerinden üretilen Van Otlu Peynirlerinin fiziksel ve kimyasal özellikleri ile proteoliz profillerinde olgunlaşma sürecinde meydana gelen değişimler. Gıda, 39 (3), 163-170.

Urry, J. (1990). The tourist gaze. (First Edition). London: Sage publication.

Usal, A. \& Oral, S.(2001). Turizm Pazarlaması. İzmir: Kanyılmaz Matbaası.

Uzunsoy, I. \& Özer, B. (2018). Cheeses from Turkey. In P. Papademas \& T. Bintsis (Eds.), Global Cheesemaking Technology, (pp.191192), Wiley, Ltd., Hoboken.

Uzundumlu, A. S. \& Topcu, Y. (2016). Determining Turkish consumers' consumption satisfaction with Erzurum Civil cheese. British Food Journal, 118(4), 896-914. 
Veal, A. J. (2018). Research methods for leisure and tourism. 5th Edition. Pearson Education Limited, UK.

Velčovská, Š. \& Sadílek, T. (2015). Certification of cheeses and cheese products origin by EU countrie. British Food Journal, 117(7), $1843-1858$

Xiao, H. \& Smith, S. L. (2006). Case studies in tourism research: A state-of-the-art analysis. Tourism Management, 27(5), 738-749.

Yanık, A. (2015). Turizmde örnek olay analizinin kullanımı. A. Yüksel, A. Yanık \& R. Ayazlar (Ed.), Bilimsel araştırma yöntemleri içinde (ss.247-261). Ankara: Seçkin Yayıncılık.

Yenipınar, U., Köşker, H. \& Karacaoğlu, S. (2014). Turizmde yerel yiyeceklerin önemi ve coğrafi işaretleme: Van Otlu Peyniri. Journal Of Tourism And Gastronomy Studies, 2(2), 13-23

Yetkin, F. B. \& Çamur, K. C. (2019). Arkeolojik Sit Alanlarında Yönetim Planlamasının Turizme Etkisinin Değerlendirilmesi; Şanlıurfa Örneği. Harran Üniversitesi Mühendislik Dergisi, 4(3), 38-48.

Yıldırım, A. \& Şimşek, H. (2018). Sosyal bilimlerde araştırma yöntemleri (11. Baskı). Ankara: Seçkin Yayınları.

Yin, R. K. (2014). Case study research and applications: Design and methods 5. Edition. London: Sage Publications.

Yin, R. K. (2017). Case study research and applications: Design and methods 6. Edition. Sage publications.

Zengin, B. \& Gürkan, A. S. (2019). Afyonkarahisar mutfağının gastronomi turizmi açısından değerlendirilmesi. Safran Kültür ve Turizm Araştırmaları Dergisi, 2(2), 225-240.

\section{İnternet Kaynakları}

Alkmaar Cheese Museum. (2019). https://www.holland.com/global/ tourism/destinations/more-destinations/alkmaar/alkmaar-cheese-museum-.htm, Erişim Tarihi: 28.11.2019

Alkmaar Cheese Market. (2019). https://www.holland.com/global/ tourism/information/events/the-cheese-market-of-alkmaar. htm Erişim Tarihi: 28.11.2019

Divle Obruğu.(2019). http://www.obrukpeyniri.com/ Erişim Tarihi: 28.11.2019

Dutch Cheese Shops. (2019). https://www.holland.com/global/ tourism/information/general/traditional-food/dutch-cheese-shops.htm, Erişim Tarihi: 28.11.2019

Gouda cheese market (2019). https://www.holland.com/global/tourism/destinations/provinces/south-holland/gouda-cheese-market.htm, Erişim Tarihi: 28.12.2019

Eurobound Launches New Europe Tours For Cheese Lovers. (2019). https://www.travelagentcentral.com/tours/eurobound-launches-new-europe-tours-for-cheese-lovers, Haber Tarihi: 14 Feb 2017, Erişim Tarihi: 05.12.2019

In situ. (2019). https://www.arkeolojikhaber.com/haber-in- situ-73 00/, Erişim Tarihi: 10.11.2019

TÜRKPATENT (2020). https://www.ci.gov.tr/cografi-isaretler/liste? il=65 Erişim Tarihi: 28.10 .2020

Türk Patent ve Marka Kurumu. (2018). Türkiye'nin Coğrafi İşaretleri Van Otlu Peyniri. https://Www.Ci.Gov.Tr/Files/Geographicalsigns/5c08a8d5-8481-48a9-911e-8a5a1b3186b2.Pdf., Erişim Tarihi: 01.11.2019

Türkiye'nin ilk peynir müzesi, https://www.sozcu.com.tr/hayatim/ seyahat/turkiyenin-ilk-peynirmuzesi/?utm_source=dahafazla_haber\&utm_medium=free\&utm_campaign=dahafazlahaber, Haber tarihi: 14.02.2019, Erişim Tarihi: 04.10.2019

Van'da 250 Yıllık Otlu Peynir Bulundu. (2015). En Son Haber. https: //www.ensonhaber.com/vanda-250-yillik-otlu-peynir-bulundu -2015-08-07.html, Haber tarihi: 07.08.2015, Erişim Tarihi: 04.10 .2019
Visit our cheese farms. (2019). https://henriwillig.com/en/abouthenri-willig/, Erişim Tarihi: 28.12.2019

\section{Görsel Kaynakça}

Fotoğraf 1. Zavot Peynir Müzesi (2020).

http://karsevleri.com/karsta-nerelere-gidilir/zavot-peynir-muzesi Erişim Tarihi: 28.11 .2020

Fotoğraf 2. Divle obruk galeri (2019).

http://www.obrukpeyniri.com/ Erişim Tarihi: 28.11.2019

Fotoğraf 3.Alkmaar Cheese Museum. (2019). Alkmaar Cheese Market. (2019).

https://www.holland.com/global/tourism/destinations/more-destinations/alkmaar/alkmaar-cheese-museum-.htm, Erişim Tarihi: 28.11.2019;

https://www.holland.com/global/tourism/information/events/ the-cheese-market-of-alkmaar.htm, Erişim Tarihi: 28.11.2019

Fotoğraf 4. Gouda cheese market (2019).

https://www.holland.com/global/tourism/destinations/provinces/ south-holland/gouda-cheese-market.htm

Fotoğraf 5. Visit our cheese farms (2019). https://henriwillig.com/ en/about-henri-willig/, Erişim Tarihi: 28.12.2019

Fotoğraf 6. Van'da 250 yıllık otlu peynir bulundu. (2015).

En Son Haber. https://www.ensonhaber.com/vanda- 250-yillik-otlu-peynir-bulundu-2015-08-07.html, Haber tarihi: 07.08.2015, Erişim Tarihi:04.10.2019

\section{Fotoğraf 7. Van otlu peynir (2019)}

https://www.trthaber.com/haber/kultur-sanat/van-kahvaltilarini-lezzetlendiren-otlu-peynir-artik-tescilli-385288.html., https://van.ktb.gov.tr/TR-88271/otlu-peynir.html, Erişim Tarihi: 28.12.2019

Fotoğraf 8 . Kültür rotası 1'de yer alan doğal ve kültürel değerlerden görünüm

https://www.google.com/maps/Ölmez 2109.Akçalı Traverten,Erişim Tarihi: 25.12.2019

Bartholomeus Kilisesi, Başkale/ VAN Tweet added by özgür eren atalay - Download Photos | Twipu

Başkale Albayrak Köyü Albayrak Aziz Bartholomeus Manastırı. Başkale Ziraat Odası http://baskale.ziraatodasi.org.tr/basin-odasi/ fotograflar/baskale-albayrak-koyu---albayrak-aziz-bartholomeus-manastiri, Erişim Tarihi: 25.12.2019

Van Gürpınar İlçesi. (2019). https://www.vanhaber.com.tr/gurpinar-ilcesi/, Erişim Tarihi: 25.12.2019, Haber Tarihi: 25.12.2020

Fotoğraf 9. Kültür rotası 2'de yer alan doğal ve kültürel değerlerden görünüm

Çavuştepe Antik Urartu Kalesi.(2019). https://gezilecekyerler.com/ cavustepe-antik-urartu-kalesi/ Haber Tarihi: 20.12.2016, Erişim Tarihi: 26.12.2019

Hoşap Kalesi Osmanlı Dönemine aittir, https://www.sabah.com.tr/ galeri/yasam/hosap-kalesi-osmanli-donemine-ittir/7, Güncelleme Tarihi: 12.08.2017, Erişim Tarihi: 26.12.2019

Tarihi hoşap kalesi eski görkemine kavuşuyor. (2019). (Fotoğraf: Ali İhsan Öztürk-Anadolu Ajansı) https://www.aa.com.tr/tr/pg/foto-galeri/tarihi-hosap-kalesi-eski-gorkemine-kavusuyor/0, Erişim Tarihi: 29.12.2019

Van'da Urartuların 2800 Yıllık Kanalizasyon Sistemi Ortaya Çıkarıldı. (2019). https://arkeofili.com/vanda-urartularin-2800-yillik-kanalizasyon-sistemi-ortaya-cikarildi/ Haber Tarihi: 24 Eylül 2016, Erişim Tarihi: 26.12.2019

Van Gürpınar İlçesi. (2019). https://www.vanhaber.com.tr/gurpinar -ilcesi/ Haber Tarihi: 20.12.2019, Erişim Tarihi: 26.12.2019 
Van'ın otlu peyniri tescillendi.(2019). https://www.aa.com.tr/tr/vg/ video-galeri/vanin-otlu-peyniri-tescillendi/0\#, Erişim Tarihi: 26. 12.2019

Fotoğraf 10. Kültür rotası 3'de yer alan doğal ve kültürel değerlerden görünüm

Çiçeklere bürünen Akdamar Adası görsel şölen sunuyor. https:// www.ntv.com.tr/galeri/seyahat/ciceklere-burunen-akdamara-dasi-gorsel-solen-sunuyor, mm6pOHSEvE-D83n0opYBWQ/ io-CAvy1cuOKVCROjJosgnw Haber Tarihi: 20.04.2019, Erişim Tarihi: 26.12.2019

Hoşgörü adası Akdamar, tüm ihtişamıyla ziyaretçilerini ağırlıyor. https://www.aa.com.tr/tr/turkiye/hosgoru-adasi-akdamar-tum -ihtisamiyla-ziyaretcilerini-agirliyor/1463188, Haber Tarihi: 26. 04.2019, Erişim Tarihi: 26.12.2019

Gevaş http://gezilecekyerler.com/gevas/,Haber Tarihi: 25.12.2016, Erişim Tarihi: 26.12.2019

Inverted tulips a visual feast in Van http://ww.hurriyetdailynews. com/inverted-tulips-a-visual-feast-in-van-143052, Haber Tarihi: 30 April 2019, Erişim Tarihi: 26.12.2019

Fotoğraf 11. Kültür rotası 4'de yer alan doğal ve kültürel değerlerden görünüm

Dönerdere Köyü. http://caykaragundem.com/haber/donerdere-koyu-5235.html Haber Tarihi: 9.2.2017, Erişim Tarihi: 27.12.2019

Yarım asırdır Van'da Karadeniz rüzgarı estiriyorlar! Trabzon'dan göç ettiler... http://www.hurriyet.com.tr/seyahat/galeri-yarim-asirdir-vanda-karadeniz-ruzgari-estiriyorlar-41107749/1, Haber Tarihi: 06.02.2019, Erişim Tarihi: 27.12.2019

Van'da Doğu'nun Kanatları Van Erçek Gölü 8. Flamingo Festivali. https://www.trthaber.com/haber/yasam/vanda-dogunun-kanatlari-van-ercek-golu-8-flamingo-festivali-387123.html, Son Güncelleme 30.09.2018, Erişim Tarihi: 27.12.2019

Van II Kültür ve Turizm Müdürlüğü. https://van.ktb.gov.tr/TR- 5216 0/fotograf-galerisi.html , Erişim Tarihi: 27.10.2020

Fotoğraf 12. Kültür rotası 5'de yer alan doğal ve kültürel değerlerden görünüm

İstanbul'daki uluslararası mutlu kediler yarışmasının birincisi o oldu https://www.haber3.com/foto-galeri/hayvanlar-alemi/istanbuldaki-uluslararasi-mutlu-kediler-yarismasinin-birincisio-oldu-galeri-5054903 Haber Tarihi: 07.10.2019, Erişim Tarihi: 28.12.2019

Kalecik. https://mapio.net/pic/p-36959072/

Van Kalesi. https://van.ktb.gov.tr/TR-76401/van-kalesi.html, Erişim Tarihi: 28.12.2019

Van kedilerinin sırrı şaşırtıyor. http://www.yenimesaj.com.tr/vankedilerinin-sirri-sasirtiyor-H1325888.htm, Haber Tarihi: 03.09. 2019, Erişim Tarihi: 28.12.2019
Van'da kadınlara gümüş işlemeciliği kursu.http://www.hurriyet.com. tr/vanda-kadinlara-gumus-islemeciligi-kursu-40240153 Haber Tarihi: 05.10.2016, Erişim Tarihi: 28.12.2019

Fotoğraf 13. Çok günlük rotalarda yer alan doğal ve kültürel değerlerden görünüm

Altınsaç Klisesi. https://van.ktb.gov.tr/TR-76515/altinsac-kilisesi.html, Erişim Tarihi: 15.12.2019

Doğanın hediyesi: Muradiye Şelalesi. https://www.sozcu.com.tr/hayatim/seyahat/doganin-yaptigi-bir-beste-muradiye-selalesi/?_szc_galeri=1, Haber Tarihi: 27.0 3 . 2019, Erişim Tarihi: 29. 12.2019

Hem doğa hem mühendislik harikası, https://www.trthaber.com/haber/gundem/hem-doga-hem-muhendislik-harikasi -81852. html Haber Tarihi: 10.4.2013, Erişim Tarihi: 29.12.2019

İnci kefalinin tatlı sulara göçü başladı https://www.ntv.com.tr/galeri/turkiye/inci-kefalinin-tatli-sulara-gocu-basladi,bs-4816QM0Oy8JZJNbMonw Haber Tarihi: 19.05.2017, Erişim Tarihi: 29.11.2019

Vanadokya. https://www.neredekal.com/vanadokya/, Erişim Tarihi: 29.12.2019

Urartuların dikili taşları turizme kazandırılıyor https://www.hurriyet. com.tr/urartularin-dikili-taslari-turizme-kazandiriliy-40911255 Haber Tarihi: 28.07.2018, Erişim Tarihi: 15.10. 2020

Şekil 1. Van İli Lokasyon Haritası ve Ana Peynir Üretim Sahaları Kaynakça: Google Haritalar, 2020

Şekil 2. Kültür Rotası 1. Harita Üzerinde Gösterimi Kaynakça: Google Haritalar, 2020

Şekil 3. Kültür Rotası 2. Harita Üzerinde Gösterimi Kaynakça: Google Haritalar, 2020

Şekil 4. Kültür Rotası 3. Harita Üzerinde Gösterimi Kaynakça: Google Haritalar, 2020

Şekil 5. Kültür Rotası 4. Harita Üzerinde Gösterimi Kaynakça: Google Haritalar, 2020

Şekil 6. Kültür Rotası 5. Harita Üzerinde Gösterimi Kaynakça: Google Haritalar, 2020 